\title{
Key Human Capital
}

\author{
Ryan D. Israelsen and Scott E. Yonker*
}

\begin{abstract}
Firms whose human capital is concentrated in a few irreplaceable employees lack diversification in their human capital stock, exposing them to key human capital risk. Using disclosures of "key man life insurance" to measure this risk, we show that exposed firms are riskier. These younger, smaller, growth firms have abnormally high volatility, and following announcement of key employee departures, the most exposed firms lose $8 \%$ of their value. Key employees tend to be highly educated. They are four times more likely to hold $\mathrm{PhD}$ degrees than top managers, and firms with key human capital are more innovative.
\end{abstract}

If we are not able to attract and retain key management and scientific personnel and advisors, we may not successfully develop our drug candidates or achieve our other business objectives.

_Idenix Pharmaceuticals S1 Filing (May 20, 2002)

\section{Introduction}

Academics have long noted that investment in human capital is riskier than investment in physical capital. ${ }^{1}$ Firms risk the loss of human capital that occurs when employees depart. Whereas research on human capital risk typically focuses on the human capital of rank-and-file employees, ${ }^{2}$ we investigate the human capital risk posed by a different set of employees: "key" employees.

\footnotetext{
*Israelsen (corresponding author), risraels@indiana.edu, Kelley School of Business, Indiana University; and Yonker, syonker@cornell.edu, Dyson School of Applied Economics and Management, Cornell University. We thank Zhi Da, Clifton Green, Yaniv Grinstein, Jarrad Harford (the editor), Andrew Karolyi, Chris Parsons, Veronika Pool, Noah Stoffman, and Rebecca Zarutskie (the referee) for detailed comments and participants of seminars at Cornell University, Utah State University, the Florida State Sun Trust Conference, the 2012 Conference on Financial Economics and Accounting (CFEA) at the University of Southern California, and the Indiana University Finance Brown Bag for helpful comments. We thank Jimmy Holden for excellent research support. Previous versions of this paper were circulated under the title "The Key Man Premium."

${ }^{1}$ See the seminal works of Becker (1964) and Levhari and Weiss (1974).

${ }^{2}$ See, for example, Brynjolfsson and Hitt (2003), Hempell (2003), Cummins (2005), Abowd, Haltiwanger, Jarmin, Lane, Lengermann, McCue, McKinney, and Sandusky (2005), Lev, Radhakrishnan, and Zhang (2009), Israelsen (2011), and Eisfeldt and Papanikolaou (2013).
} 
The motivation for focusing on these employees is simple. A key employee, by definition, possesses a larger fraction of the firm's human capital than the typical worker. In addition, the type of human capital that key employees possess, "key human capital," is different from that of ordinary employees because replacement is difficult, if not impossible. Training alone cannot replace all that is lost when a key employee departs. Key employees may be scientists who develop high-tech products or managers with crucial relationships with clients or suppliers. ${ }^{3}$ Consequently, losing a single key employee could be much more costly to a firm and its shareholders than losing numerous rank-and-file employees. In this paper, we investigate this new type of human capital risk: key human capital risk. We document the types of firms that are exposed and provide evidence that exposed firms are indeed riskier.

To illustrate key human capital risk, consider the case of Idenix Pharmaceuticals. On Oct. 28, 2010, Idenix, a small, Cambridge, MA-based company that specializes in the development of drugs for the treatment of hepatitis $\mathrm{C}$ (HVC) and human immunodeficiency virus (HIV), announced that Jean-Pierre Sommadossi resigned to "pursue other interests in the biotech field." " Not only was Sommadossi the founder, chief executive officer (CEO), and chairman of Idenix, but he also holds a $\mathrm{PhD}$ in pharmacology and is the holder of more than 50 patents related to the treatment of HVC and HIV. Idenix's stock price immediately fell on the announcement, with cumulative abnormal returns (CARs) of $-10 \%$ within 5 days and $-20 \%$ within a month. ${ }^{5}$

Realizing that losing Sommadossi would be detrimental, Idenix previously disclosed that "the loss of the service of any of the key members of [its] senior management may significantly delay or prevent the achievement of product development and other business objectives." In its U.S. Securities and Exchange Commission (SEC) filings, Idenix had named Sommadossi as one of those key members of management and had taken measures to protect itself from the losses it would incur in the event of Sommadossi's death by maintaining a "key man" insurance policy on his life. ${ }^{6}$ However, the company had not hedged the more probable event: his voluntary departure.

This example highlights several important features of key human capital risk and of our study. First, key human capital risk should be relevant only to firms in which human capital plays an important role. The development of pharmaceuticals is one such case. Second, although we hypothesize that losing a key employee is detrimental to firms in general, one property of key human capital that makes it particularly risky is its concentration. Thus, the risk will be greatest for smaller firms with few employees. For Idenix, Sommadossi's departure was much more detrimental than it otherwise would have been for a larger pharmaceutical company with many scientists. Finally, the Idenix example shows how we are able to identify key employees and firms that are exposed to key human capital risk through their SEC disclosures of key man life insurance.

\footnotetext{
${ }^{3}$ For example, Karolyi (2013) shows that the personal banking relationships of chief financial officers (CFOs) lead to better loan terms.

${ }^{4}$ See "Idenix Says CEO Resigns, Promotes CFO,” Reuters News (Oct. 28, 2010).

${ }^{5}$ CARs are computed using the capital asset pricing model (CAPM).

${ }^{6}$ Idenix Pharmaceuticals S1/A Filing (May 20, 2002).
} 
A key man life insurance policy is simply a life insurance policy on a key employee that lists the employee's firm as the beneficiary. Firms pay monthly or annual premiums for these policies, which are priced just like ordinary life insurance policies. Upon the death of the employee, the corporation receives the face value of the insurance policy. As is the case with most life insurance policies, the firm must have an insurable interest in the key employee in order to designate itself as the beneficiary. Not surprisingly, most firms purchase key man insurance because of their dependence on these key employees. However, it is not always the firm that recognizes the risk; sometimes a lender will require the firm to hold key man insurance as part of a loan covenant. ${ }^{7}$

Disclosure of these policies is not mandatory; however, the SEC requires all listed firms to "provide a discussion of the most significant factors that make the offering speculative or risky." 8 Disclosures of key man insurance are often made to comply with this rule. We utilize these key man insurance disclosures to i) identify firms that are exposed to key human capital risk, ii) quantify exposure levels, and iii) identify key employees.

We use the disclosure itself as a method for identifying firms that are exposed to key human capital risk in general. Key employees can leave their firms voluntarily or through death. Because these policies hedge death, not turnover (the more common and potentially systematic type of employee departure), both firms that disclose that they $d o$ and those that disclose they do not carry key man insurance policies are considered exposed to key human capital risk. Firms that carry key man insurance remain exposed to the risk of voluntary departure, whereas firms that do not carry such insurance but find it material to disclose their lack of coverage are exposed to the risk of both types of departure. Thus, our broadest measure of key human capital risk exposure is an indicator variable that we call KEY_HUMAN_CAPITAL. It is equal to 1 if a firm discloses whether it carries key man insurance and is 0 if no mention of key man insurance is made in the firm's SEC filings. ${ }^{9}$

Although KEY_HUMAN_CAPITAL is a broad measure, covering all firms, it is also coarse. For a subset of exposed firms, we are able to refine our measure to quantify the key human capital risk exposure of firms. Firms that choose to insure their key employees often disclose the insurance policy amounts and covered key employees. Assuming that firms fully insure their losses from key employee deaths, key man policy amounts reveal the value of the firm-specific portion of key human capital. ${ }^{10}$ We aggregate harvested policy amounts by firm and create the measure we call KEY_HUMAN_CAPITAL_INTENSITY, which is the ratio of the total key man insurance policy amounts to the book value of assets. ${ }^{11}$ Because the key employees are the source of key human capital risk, we also harvest these

\footnotetext{
${ }^{7}$ See Appendix A for examples of key man life insurance disclosures from SEC filings.

${ }^{8}$ Instructions to Item 503(c) ("Risk Factors") of Regulation S-K.

${ }^{9}$ Our data are available for download at http://ryan.israelsen.com.

${ }^{10}$ The literature makes the distinction between firm-specific human capital and general human capital. We elaborate on this later. The policy amounts reflect the firm-specific portion because firms insure their losses beyond replacement of the employee.

${ }^{11}$ Policy amounts are scaled by assets because key human capital should be riskiest when it represents a significant portion of the firm's total assets.
} 
key employee names and use them to estimate the impact of key person voluntary departure on firm value.

Approximately $20 \%$ of U.S. nonfinancial firms from 1997 to 2009 are exposed to key human capital risk, and total key man policy amounts average roughly $10 \%$ of the book value of assets. Exposed firms tend to be younger, smaller, growth firms, with fewer tangible assets that invest more in research and development (R\&D). They are also more likely to be concentrated in what are generally considered human-capital-intensive industries, such as pharmaceutical products and the computer programming segment of the business services industry. Key employees tend to be highly educated. Many key employees hold doctoral degrees, and most majored in either engineering or a hard science as undergraduates. This contrasts with CEOs of large firms, who are more likely to hold professional degrees.

We begin our analysis by testing whether firms with key human capital are more risky. We do so by regressing both total and idiosyncratic stock return volatilies on our measures of key human capital and control variables. We find that firms exposed to key human capital risk have total and idiosyncratic stock return volatilities that are roughly 5\%-20\% higher than those of firms that are not exposed. We perform additional tests to rule out two important potential sources of endogeneity.

First, some firms are required to carry key man policies to satisfy loan covenants, suggesting that firms holding key man insurance are financially constrained. This could be the true mechanism driving the riskiness of these firms. However, controlling for measures of financial constraints has no effect on our inferences, and it is the disclosure of key man insurance, not whether firms actually carry the insurance, that drives higher risk levels.

The second potential source of endogeneity is that firms with a higher propensity to make risk disclosures in general may be more risky than their peers, suggesting that a more general "disclosure effect" drives the relationship between key human capital and risk. To address this concern, we include in the control variables a proxy for a firm's propensity to voluntarily disclose information based on nonmandatory $8-\mathrm{K}$ disclosure filings. We find that although greater disclosure is associated with greater volatility, firms that are exposed to key human capital risk are risky beyond this disclosure effect. In addition, when testing within the set of exposed (disclosing) firms, we find that firms with greater exposure to key human capital risk have greater total and idiosyncratic volatility.

We next conduct an event study to directly examine shareholder wealth effects around the voluntary departure of key employees. To the extent that the marginal product of employees' human capital exceeds their compensation, human capital affects firm value. When human capital is general and labor markets are efficient, wages will fully compensate employees' human capital. However, employees with firm-specific human capital (e.g., key human capital or organizational capital) may have fewer outside options. ${ }^{12}$ As a result, firms may not need to fully compensate employees. Moreover, if there are complementarities between

\footnotetext{
${ }^{12}$ Becker (1964) is the first to distinguish between the impact of general and firm-specific human capital on firm value.
} 
human capital and other types of fixed or intangible capital in a firm's production process, the amount of human capital in a firm and the firm's value will be correlated even if employees are fully compensated.

The results are consistent with that of the regression analysis: The loss of key employees poses a substantial risk to their firms. Defining key employees as those who are the subjects of key man life insurance policies, we find significant, negative abnormal stock returns of approximately $4 \%$ in the 4 days following the departure announcement. Furthermore, the impact is the largest for firms with the most concentrated key human capital. When splitting the sample based on key human capital intensity, firms in the top half have negative abnormal returns of approximately $8 \%$ following turnover events. These results are not driven by the contemporaneous release of negative firm news because we are careful to include in our event study sample only observations for which no other major news announcements were made on the same day.

However, one might be concerned that key employees depart prior to the announcement of bad news and that market participants react negatively to their departure not because of the loss of the key employee but because they view the resignation of the key employee as a signal of negative future company news. Although this possibility is difficult to eliminate entirely, a number of facts reduce this concern. First, we find that the reduction in firm value during the event period is stronger in firms with greater exposure to key human capital risk. This crosssectional difference is not implied by the alternative story. Second, the literature on voluntary departures of CEOs finds the opposite effect: When CEOs leave, the market reaction is positive or insignificant (Warner, Watts, and Wruck (1988), Denis and Denis (1995)). Presumably, CEOs should have as much, if not more, knowledge of their firm's future prospects than should key employees, so it is not clear why this would cause the market to react differently to key employee departures than to CEO departures.

Having shown that key human capital is risky, we investigate one potential source of value that key employees may generate: innovation. Although not all key employees are scientists or researchers, a substantial proportion of key employees hold advanced degrees, and key employees are often found in innovative industries. Thus, we test whether firms with key human capital are more innovative, on average. When we use patents as a measure of innovation, the results indicate that firms with key human capital produce approximately $9 \%$ more innovation per year than do similar firms without key human capital. We find similar results when we measure innovation using patent citations. Although we do not completely rule out the possibility that firms that are more innovative are more likely to make key man life insurance disclosures, we show that within the set of firms making these disclosures, the firms with key employees who are doctors (hold $\mathrm{PhD}$ or MD degrees) produce greater innovation than those whose key employees do not hold these degrees. This suggests that the firms with the human capital necessary to produce greater innovation are the ones driving the results.

We conclude the analysis by investigating whether investors require compensation for exposure to key human capital risk. Studies proposing that the human capital risk of rank-and-file employees is systematic rely on the distinction between firm-specific and general human capital (Eisfeldt and Papanikolaou (2013), 
Donangelo (2011)). Although the employee's general human capital is retained by the employee following turnover, the firm-specific portion is lost to the original firm and is useless to the employee's new firm. If turnover is systematic, investors cannot hedge this risk. ${ }^{13}$ Following this same logic, if the turnover of key employees is systematic, then there should be a systematic component to key human capital risk.

We test whether key human capital risk is systematic by examining whether investors require a premium to hold firms that rely more on key human capital, and we find mixed evidence. When we conduct cross-sectional tests using stock portfolios based on KEY_HUMAN_CAPITAL, we find no evidence of a premium for firms with key human capital. However, stocks in these two portfolios are very different. In particular, stocks with key human capital tend to be small, growth firms, which have anomalously low returns (Fama and French (1993)). In addition, investors should care about the firm-specific portion of human capital. Therefore, we conduct tests within the set of firms for which we can measure key human capital intensity.

We find that firms with high key human capital intensity have significantly greater returns than those with low key human capital intensity. The difference in risk-adjusted returns is $0.84 \%-1.20 \%$ per month, depending on the asset pricing model utilized. However, when we perform portfolio tests within small and large firms, we find that the premium exists only within portfolios of small firms. This is consistent with the idea that key human capital in small firms should be particularly risky because their key human capital will be more concentrated than that of large firms. These results provide preliminary evidence on the asset pricing implications of key human capital.

This paper makes a number of contributions to the literature on human capital and risk. First, we identify and investigate a new type of human capital: key human capital. Prior research has focused on the human capital of rank-and-file employees and has relied on indirect measures of human capital. ${ }^{14}$ For a subset of our firms, we are able to directly measure the firm-specific portion of key human capital. Using our measures, we show that firms with high key human capital intensity are riskier than their counterparts. These firms have greater stock volatility, and value declines when key employees voluntarily depart. We also provide evidence of one potential source of key employee value: innovation. To our knowledge, the only other study that shows that a particular employee characteristic is associated with greater innovation is that by Hirshleifer, Low, and Teoh (2012), who show that overconfident CEOs are better innovators. Finally, we provide preliminary evidence that key human capital risk is important to diversified investors,

\footnotetext{
${ }^{13}$ In the model of Eisfeldt and Papanikolaou (2013), for example, systematic turnover is induced by economy-wide technology shocks.

${ }^{14}$ For example, a number of studies use investment in information technology capital as a proxy for investment in human capital (Brynjolfsson and Hitt (2003), Hempell (2003), Cummins (2005), and Israelsen (2011)), whereas others use accumulated selling, general, and administrative (SG\&A) expense to assets to measure organizational capital (Lev et al. (2009), Eisfeldt and Papanikolaou (2013)). Abowd et al. (2005) estimate human capital at the firm level using employee-level wage data from the U.S. Census Bureau.
} 
showing that investors require a premium for exposure to key human capital risk in small firms.

Our findings are also related to the literature on the human capital and skills of CEOs. Several studies focus on the distinction between CEO firm-specific and general human capital and its implications for executive pay (Murphy and Zabojnik (2007), Cremers and Grinstein (2014), and Custódio, Ferreira, and Matos (2013)). Others assess which CEO skills matter for firm performance using identifiable CEO characteristics (Kaplan, Klebanov, and Sorensen (2012), Falato, Li, and Milbourn (2014)). Our study differs from these in two important of ways. First, whereas papers in the CEO literature mainly focus on pay and performance, we are primarily concerned with risk. ${ }^{15}$ Second, we focus on a different set of employees: key employees. Although one might argue that CEOs are key employees, we show that this is not necessarily true. Not only do key employees have different training than CEOs, but our results on key employee turnover stand in contrast to a puzzling finding in the corporate finance literature: Event studies of the death or departure of executives show zero or positive abnormal returns after a death (Johnson, Magee, Nagarajan, and Newman (1985), Borokhovich, Brunarski, Donahue, and Harman (2006)) or an unanticipated departure (Warner et al. (1988), Denis and Denis (1995)). So although not all executives are key employees, we identify those whose human capital is truly important to their firms.

\section{Data}

This study uses key man life insurance disclosures from SEC filings to identify firms exposed to key human capital risk. The SEC requires all firms listed on the New York Stock Exchange (NYSE), NASDAQ, and the American Stock Exchange (AMEX) to file various forms and reports. Item 503(c) ("Risk Factors") of Regulation S-K instructs filers to "provide under the caption 'Risk Factors' a discussion of the most significant factors that make the offering speculative or risky." Regulation S-K initially applies to a firm when it files Form S-1, the "Registration Statement under the Securities Act of 1933." However, it also applies to continual reporting requirements in other documents (e.g., Forms 10-Q, 8-K, and 424). ${ }^{16}$ For example, when filing Form $10-\mathrm{K}$, firms are instructed to disclose risks according to Item 503(c). These are to be included in Item 1A ("Risk Factors") of the annual report. As of May 6, 1996, all public domestic companies are required to make their filings available to the SEC in electronic format. We search these filings for every firm listed on NYSE/AMEX/NASDAQ (exchange codes 1, 2, and 3 in the Center for Research in Security Prices (CRSP) data) excluding financial firms (Standard Industrial Classification (SIC) codes between 6000 and 6999) through 2009.

\footnotetext{
${ }^{15}$ The exception is Adams, Almeida, and Ferreira (2005), who show that firms run by powerful CEOs are more risky. In their case, concentration in decision making makes firms more risky, whereas in our study, it is the concentration of human capital that leads to greater risk.

${ }^{16}$ The firm (and its directors and officers) is subject to potential legal liabilities for omissions or misstatements in the registration statement and in subsequent filings.
} 
To identify disclosures of key man insurance, we search through every electronic filing of each firm. ${ }^{17}$ This is a multistep process. First, we use a computer script to search each filing for phrases such as "key man life insurance," "key person life insurance," "key executive life insurance," "key woman life insurance," and derivations thereof. When there is a match, we save the 300 characters before and after the matched phrase. Next, we read through each of these matches to determine whether or not these disclosures are truly related to risks associated with key employees. If so, we classify the match as "Disclose/Yes." We classify the few matches unrelated to this risk as "Disclose/No." Next, we further classify the subset of matches in the category "Disclose/Yes." These matches are placed into the subcategory "Insure/Yes" if the firms mention that they carry key man insurance on at least one key employee and "Insure/No" if they mention that they do not carry such policies.

After classifying each of the matches from the individual filings, we aggregate to the firm-year frequency. A subset of the filings indicating "Insure/Yes" also includes information on the names and positions of the covered employees and the face value of the policies, all of which we manually collect. Policy amounts are aggregated to the firm-year level.

In some cases, firms purchase key man life insurance for an employee as a form of compensation. For example, the heir of a key employee may be listed as the beneficiary. We are careful to exclude these. Only corporate-owned life insurance policies are included. We do not include any insurance policies unless the employee is described as "key." Examples of the text of key man insurance disclosures are found in Appendix A. Additionally, Appendix B provides a list of 50 firms that make key man life insurance disclosures as well as the filing type, the filing date, the key employee(s), and the policy amounts, when applicable. This is a representative sample that includes both large and small firms and disclosures covering almost every year of the sample period across a variety of filing types.

Occasionally, firms disclose coverage only when the policy is initially purchased or when there is a change in coverage. For example, the firm OSI Systems, Inc., first reports in its S-1/A filing of Aug. 1, 1997, that "The Company [...] maintains a $\$ 13$ million policy of key man life insurance on the life of Mr. Chopra." OSI discloses the same amount of insurance on Mr. Chopra each year from 2001 through 2007. In this example, we assume that OSI maintained the \$13 million policy on Deepak Chopra's life for the years 1998-2000. In general, we use the firm's most recent statement as an indication of the type and amount of coverage. This is based on the assumption that firms are more likely to disclose a change in coverage than to repeatedly disclose the same information.

Based on the key man life insurance disclosure data, we have two main categories of interest: "Disclose/Yes" and "Disclose/No." Recall that firms making any disclosure about key man insurance on key employees are likely to be exposed to key human capital risk, regardless of whether they choose to insure. Thus, we define our broadest measure of key human capital risk exposure as an indicator

\footnotetext{
${ }^{17}$ Typically, firms disclose whether they carry key man life insurance in Item 1A ("Risk Factors") of the annual report. However, they may also do so in other filings. Accordingly, we search through every form on the SEC's Web site (www.sec.gov/edgar/searchedgar/companysearch.html).
} 
variable that we call KEY_HUMAN_CAPITAL. We set this variable equal to 1 for firms in the "Disclose/Yes" category and 0 for firms in the "Disclose/No" category.

Figure 1 displays a flowchart outlining the construction of each of the key human capital measures as well as the number of firm-year observations that fall under each category. Our sample includes 8,013 unique firms, spanning 13 years, producing an unbalanced panel with 51,316 firm-year observations or an average of 3,947 firms per year. For 10,000 of these firm-year observations, firms make disclosures of key man life insurance and thus fall into the category "KEY_HUMAN_CAPITAL $=1$." There are 1,824 unique firms that make at least one key human capital disclosure. As shown in the figure, we partition these 10,000 observations into the subcategories "Insure/No" (5,186 firm-year observations) and "Insure/Yes" (4,814 firm-year observations). From this latter category, we are able to gather policy amounts for 3,516 firm-year observations. In general, there is very little within-firm variation in the disclosure of key human capital, and most firms with variation appear only briefly in the sample. ${ }^{18}$

Although the SEC states that firms should "not present risks that could apply to any issuer or any offering" and has repeatedly counseled firms to avoid "boilerplate" disclosures, ${ }^{19}$ it is still possible that a more general "disclosure effect" drives the relationship between key human capital and risk. To address this, we collect the number of nonmandatory $8-\mathrm{K}$ disclosures made by the firm. Nonmandatory 8-K disclosures are those that fall under Item 8.01, "Other Events," which is used to report "events that are not specifically called for by Form 8-K,

FIGURE 1

Construction of Key Human Capital Measures

Figure 1 displays a flowchart outlining the construction of the key human capital measures as well as the number of firm-year observations that fall under each category.

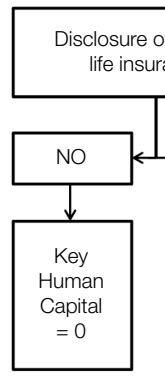

41,316

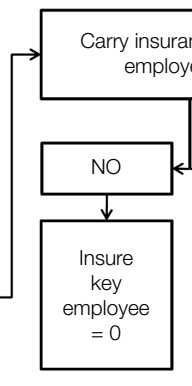

5,186

10,000

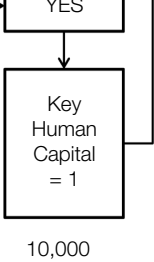$$
\text { (1) }
$$

.
}

\footnotetext{
${ }^{18}$ Our data are available for download at http://ryan.israelsen.com.

${ }^{19}$ See Regulation S-K Section 503 (http://www.gpo.gov/fdsys/pkg/CFR-2012-title17-vol2/pdf/ CFR-2012-title17-vol2-sec229-503.pdf); the Division of Corporation Finance's Updated Staff Legal Bulletin No. 7, "Plain English Disclosure" (http://www.sec.gov/interps/legal/cfslb7a.htm); and, for example, the SEC's response to Volcom's initial Registration Statement on May 25, 2005 (http:// www.sec.gov/Archives/edgar/data/1324570/000000000005026020/filename1.txt).
} 
that the registrant considers to be of importance to security holders." ${ }^{20}$ Throughout the analysis, we use the firm's number of nonmandatory $8-\mathrm{K}$ disclosures in the previous year to control for this effect.

In addition to the data gathered from SEC filings, we collect firm- and employee-level data from various sources. Because firms with key human capital tend to be small, growth firms, it is also likely that many were backed by venture capital (VC) during their initial public offerings (IPOs). Kortum and Lerner (2000) show that greater VC activity in an industry leads to greater innovation in that industry. To alleviate concerns that our key human capital measure is picking up a "VC effect," we construct a dummy variable that is equal to 1 if the firm's IPO was VC-backed (VC_BACKED_IPO) using data from the Securities Data Company (SDC) Platinum database, and 0 otherwise.

We use the CRSP/Compustat merged database to link the Central Index Key (CIK) code from the SEC to the Compustat GVKEY and the CRSP PERMNO. Compustat is used to construct firm-level accounting variables. CRSP is the source for monthly and daily stock returns, with adjustments for delisting where applicable. Data on patents and patent citations come from the 2006 edition of the National Bureau of Economic Research (NBER) patent database and the Web site of Noah Stoffman (https://kelley.iu.edu/nstoffma/), who provides data from Kogan, Papanikolaou, Seru, and Stoffman (2012) that run through 2010. Because there is often a 2-year lag between patent applications and grants, we follow Hall, Jaffe, and Trajtenberg (2001) by excluding 2004 through 2006 from the NBER patent database and 2008 through 2010 from the Kogan et al. (2012) data. Governance variables are from RiskMetrics. All variable definitions and their data sources are found in Appendix C.

Panel A of Table 1 provides summary statistics for the full sample, and Panel B provides summary statistics for the subsamples of firms based on exposure to key human capital risk. Figure 2 shows exposure to key human capital over time. Firms exposed to key human capital risk make up 19\% of all firm-year observations during the sample period. This figure increases modestly over time, from $11 \%$ in 1997 to $25 \%$ in 2009 . Of these, slightly less than half disclose that they insure the lives of key employees. This rate remains fairly steady over time at $10 \%$ of firms.

Firms exposed to key human capital risk have characteristics that differ from those that are not in ways that we would expect if these firms are more reliant on key human capital. In particular, exposed firms are much younger (over 7 years on average), smaller, and more R\&D intensive; hold fewer tangible assets; and have better growth opportunities. In addition, firms with key human capital are more likely to have been backed by VC during their IPOs and have a greater propensity to make voluntary disclosures, as measured by the natural logarithm of the number of 8-K filings. Their CEOs are more likely to be company founders and have more firm-specific skills, as measured by the General Ability Index (GAI) of Custódio et al. (2013). Although measures of volatility and innovation differ for firms with key human capital, we cannot draw conclusions based on these univariate tests

\footnotetext{
${ }^{20}$ Prior to Aug. 23, 2004, this item was known as Item 5. See "Additional Form 8-K Disclosure Requirements and Acceleration of Filing Date" (http://www.sec.gov/rules/final/33-8400.htm).
} 
because they do not control for important differences in the characteristics of these firms. We test for differences in these outcome variables in our main analysis. There are fewer differences between exposed firms that choose to insure and those that do not.

\section{TABLE 1}

\section{Sample Composition and Summary Statistics}

Panel A of Table 1 shows summary statistics for the sample of nonfinancial firms listed on the NYSE, AMEX, or NASDAQ and covered by Compustat from 1997-2009. In Panel B, the sample is split in two ways. The first two columns show summary statistics for firms that are exposed to key human capital risk (KEY_HUMAN_CAPITAL $=1$ ) and those that are not (KEY_HUMAN_CAPITAL =0). KEY_HUMAN_CAPITAL is an indicator variable that is equal to 1 if the firm discloses whether it maintains key man life insurance on any of its employees, and 0 otherwise. In columns 3 and 4 , statistics are shown for samples within the set of exposed firms. Specifically, columns 3 and 4 show summary statistics for firms that do and do not insure key employees, respectively. Standard errors in these unconditional tests are clustered at the firm level. Panel $\mathrm{C}$ shows the top 10 industries by the percentage of firms in the industry that are exposed to key human capital risk. It also shows the percentage of firms that carry key man insurance in the industry and the percentage of firms in the sample that are in the industry. The panel uses the Fama-French (1997) 48 industry classifications and requires the industry to have at least $1 \%$ of the firm-year observations in the sample. ${ }^{*},{ }^{* *}$, and ${ }^{* * *}$ indicate significance at the $10 \%$, $5 \%$, and $1 \%$ levels, respectively.

Panel A. Summary Statistics

\begin{tabular}{|c|c|c|c|c|}
\hline & Mean & Median & Std. Dev. & $N$ \\
\hline KEY_HUMAN_CAPITAL & 0.19 & 0.00 & 0.40 & 51,316 \\
\hline INSŪRE_KEY_EMPLOYEE & 0.09 & 0.00 & 0.29 & 51,316 \\
\hline TOTAL_REAL_ASSETS (\$millions) & $2,580.56$ & 239.51 & $15,269.23$ & 51,316 \\
\hline In(TOTAL_REAL_ASSETS) & 5.59 & 5.48 & 2.04 & 51,315 \\
\hline FIRM_AGE (years) & 15.84 & 10.00 & 15.66 & 51,316 \\
\hline$Q$ & 2.12 & 1.46 & 1.96 & 51,307 \\
\hline TANGIBILITY & 0.49 & 0.38 & 0.38 & 50,951 \\
\hline R\&D_INTENSITY & 0.29 & 0.00 & 1.38 & 51,316 \\
\hline LEVERAGE & 0.21 & 0.16 & 0.22 & 51,315 \\
\hline$S G \& A$ & 0.30 & 0.23 & 0.29 & 51,316 \\
\hline In(NUMBER_OF_8K_FILINGS) & 0.73 & 0.69 & 0.79 & 51,316 \\
\hline VC_BACKED_IPO & 0.21 & 0.00 & 0.40 & 51,316 \\
\hline G_INDEX & 9.02 & 9.00 & 2.65 & 13,504 \\
\hline PROP_OF_BOARD_IND & 0.68 & 0.71 & 0.18 & 14,747 \\
\hline CEO_IS_COMPANY_FOUNDER & 0.19 & 0.00 & 0.40 & 8,262 \\
\hline CEO_GENERAL_ABILITY_INDEX & 0.06 & -0.10 & 1.00 & 12,534 \\
\hline STOC̄K_VOLATILITY & 4.42 & 3.64 & 2.85 & 51,316 \\
\hline STOCK_IDIOSYNCRATIC_VOLATILITY & 4.14 & 3.33 & 2.87 & 51,316 \\
\hline NUMBER_OF_PATENTS & 10.57 & 0.00 & 92.60 & 39,679 \\
\hline NUMBER_OF_CITATIONS & 74.28 & 0.00 & 917.65 & 39,679 \\
\hline
\end{tabular}

Panel B. Sample Splits by KEY_HUMAN_CAPITAL and INSURE_KEY_EMPLOYEE

KEY

HUMAN_CAPITAL

\begin{tabular}{rr}
\hline 1 & \multicolumn{1}{c}{0} \\
$1.00^{\star \star \star}$ & 0.00 \\
$0.48^{\star \star \star}$ & 0.00 \\
$801.22^{\star \star \star}$ & $2,997.73$ \\
$4.87^{\star \star \star}$ & 5.77 \\
$9.81^{\star \star \star}$ & 17.29 \\
$2.45^{\star \star \star}$ & 2.05 \\
$0.40^{\star \star \star}$ & 0.51 \\
$0.51^{\star \star \star}$ & 0.24 \\
$0.19^{\star \star \star}$ & 0.22 \\
$0.36^{\star \star \star}$ & 0.28 \\
$0.82^{\star \star \star}$ & 0.71 \\
$0.28^{\star \star \star}$ & 0.19 \\
$8.16^{\star \star \star}$ & 9.13 \\
$0.66^{\star \star}$ & 0.68 \\
$0.40^{\star \star \star}$ & 0.17 \\
$-0.09^{\star \star \star}$ & 0.08 \\
$5.15^{\star \star \star}$ & 4.25 \\
$4.87^{\star \star \star}$ & 3.96 \\
$0.47^{\star \star \star}$ & 0.63 \\
$0.70^{\star \star \star}$ & 0.95
\end{tabular}

INSURE KEY_EMPLOYEE

\begin{tabular}{|c|c|}
\hline 1 & 0 \\
\hline 1.00 & 1.00 \\
\hline $1.00^{\text {***}}$ & 0.00 \\
\hline $460.47^{\star \star \star *}$ & $1,117.15$ \\
\hline $4.50^{\star * *}$ & 5.21 \\
\hline 9.49 & 10.10 \\
\hline 2.44 & 2.46 \\
\hline 0.38 & 0.41 \\
\hline 0.56 & 0.47 \\
\hline 0.19 & 0.19 \\
\hline $0.38^{* \star *}$ & 0.34 \\
\hline $0.78^{\star \star \star}$ & 0.86 \\
\hline 0.27 & 0.29 \\
\hline 8.13 & 8.18 \\
\hline 0.66 & 0.67 \\
\hline $0.49^{\star *}$ & 0.34 \\
\hline$-0.34^{\star \star *}$ & 0.05 \\
\hline $5.44^{* \star *}$ & 4.88 \\
\hline $5.19^{* \star *}$ & 4.56 \\
\hline $0.38^{* * *}$ & 0.55 \\
\hline $0.61^{* *}$ & 0.79 \\
\hline
\end{tabular}

(continued on next page)
KEY HUMAN CAPITAL

INSURE KEY EMPLOYEE

TOTAL_REAL_ASSETS (\$millions)

In(TOTAL REAL ASSETS)

FIRM_AGE (years)

TANGIBILITY

R\&D_INTENSITY

LEVERAGE

SG\&A

In(NUMBER_OF_8K_FILINGS)

VC_BACKED_IPO

G_INDEX

PROP OF BOARD INDEP

CEO_IS_COMPANY_FOUNDER

CEO GENERAL ABILITY INDEX

STOCK VOLATILITY

STOCK_IDIOSYNCRATIC_VOLATILITY

In(NUMBER OF PATENTS)

In(NUMBER_OF_CITATIONS) 
TABLE 1 (continued)

Sample Composition and Summary Statistics

\begin{tabular}{|c|c|c|c|}
\hline Industry & $\begin{array}{l}\text { \% of Industries with } \\
\text { KEY_HUMAN_CAPITAL = } 1\end{array}$ & $\begin{array}{l}\text { \% of Industries with } \\
\text { INSURE_KEY_EMPLOYEE }=Y\end{array}$ & $\begin{array}{c}\% \text { of Industries } \\
\text { Sample }\end{array}$ \\
\hline Pharmaceutical products & 30.0 & 15.0 & 7.5 \\
\hline Business services & 27.7 & 13.3 & 15.2 \\
\hline Petroleum and natural gas & 25.3 & 10.4 & 3.8 \\
\hline Measuring and control equipment & 24.4 & 13.6 & 2.6 \\
\hline Retail & 24.0 & 12.1 & 5.4 \\
\hline Computers & 23.3 & 11.1 & 5.3 \\
\hline Communication & 21.5 & 7.6 & 3.2 \\
\hline Electronic equipment & 21.2 & 8.2 & 7.4 \\
\hline Medical equipment & 20.5 & 12.0 & 4.0 \\
\hline Health care & 19.7 & 8.2 & 1.8 \\
\hline
\end{tabular}

FIGURE 2

Key Man Life Insurance Disclosures over Time

Figure 2 displays the percentage of firms for each year in the sample of nonfinancial firms listed on the NYSE, NASDAQ, or AMEX that are exposed to key human capital risk (KEY_HUMAN_CAPITAL), disclose that they carry key man life insurance (INSURE_KEY_EMPLOYEE $=Y$ ), and disclose that they do not carry key man life insurance $($ INSURE_KEY_EMPLOYEE $=$ N). KEY_HUMAN_CAPITAL is an indicator variable that is equal to 1 if a firm discloses whether it carries key man life insurance on any of its employees, and 0 otherwise.

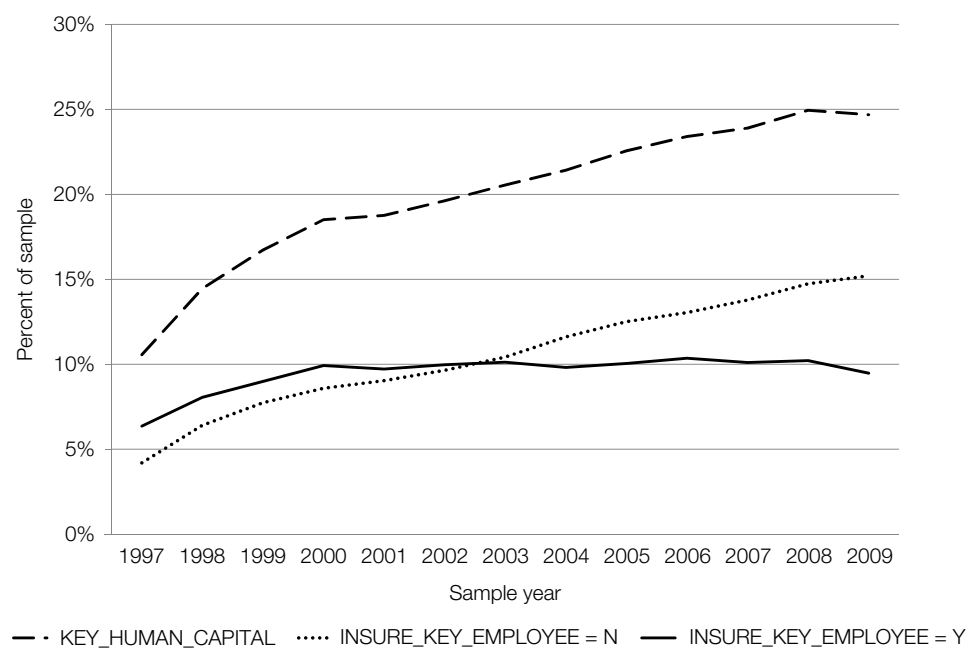

Panel C of Table 1 lists the top 10 industries by the percentage of firms within the industry exposed to key human capital risk. At 30\%, the pharmaceutical products industry has the highest percentage of firms. The industry with the second largest percentage of exposed firms is business services, at $28 \%$. The business services industry is very general, so this finding may not seem as obvious. However, when decomposing this industry by SIC codes, we find that more than two-thirds of all disclosures are made by firms in SIC code 7370, computer programming and data processing. Upon inspection of the remaining 8 industries, most of them are generally considered human capital intensive.

Approximately $70 \%$ of firms that disclose that they carry key man insurance also disclose the policy amounts. We are particularly interested in firms that 
disclose dollar amounts of life insurance coverage because these firms place a value on the firm-specific portion of the human capital of key employees. ${ }^{21}$ Panel A of Table 2 provides summary statistics for disclosed key man insurance policies. The average aggregate disclosed amount of coverage per firm is just shy of $\$ 4$ million, but the variable is as high as $\$ 60$ million. On average, 1.4 employees are covered. Summary statistics for KEY_HUMAN_CAPITAL_INTENSITY, which is the ratio of total key man policy amounts to total assets, is displayed in the fourth row of Panel A. KEY_HUMAN_CAPITAL_INTENSITY ranges from 0 to 3.31 times assets. On average, these firms place a dollar value on key employees of approximately $10 \%$ of total assets.

If key employees possess large quantities of human capital, then we should see evidence of this when looking into their educational and employment backgrounds. Panel B of Table 2 lists the positions and educational backgrounds

\section{TABLE 2}

Key Man Policy and Covered Employee Summary Statistics

Panel A of Table 2 shows summary statistics on key man corporate-owned life insurance policies for the subsample of firms that disclose key man policy amounts. There are 3,520 firm-year observations that meet these criteria. Panel $\mathrm{B}$ lists positions, academic degrees, and undergraduate majors of named key employees and executives covered by the ExecuComp database in the same years. These data are collected by searching www.nndb.com for named key employees. There are 1,171 key employees named in SEC disclosures for the sample. Educational data, undergraduate majors, and titles are found for 439, 292, and 682 key employees, respectively. Educational data for ExecuComp CEOs and top 5 earners from 1997-2009 are obtained from BoardEx. The educational background is obtained for 2,548 CEOs and 10,671 top 5 earners.

Panel A. Key Man Insurance Policy Summary Statistics

\begin{tabular}{|c|c|c|c|c|}
\hline & Mean & Std. Dev. & Min & Max \\
\hline Key man policy amount (\$millions) & 3.89 & 5.94 & 0.10 & 60.00 \\
\hline Key man policy amount (real \$millions) & 4.12 & 6.37 & 0.01 & 70.92 \\
\hline No. of employees covered & 1.41 & 0.73 & 1.00 & 7.00 \\
\hline Key human capital intensity & 0.10 & 0.19 & 0.00 & 3.31 \\
\hline \multicolumn{5}{|l|}{ Panel B. Key Employee Characteristics } \\
\hline & & & \multicolumn{2}{|c|}{ ExecuComp } \\
\hline & & Key Man & CEO & Top 5 \\
\hline Graduate education & & 65.3 & 68.4 & 66.8 \\
\hline Doctor & & 26.2 & 6.0 & 5.1 \\
\hline PhD & & 20.3 & 5.7 & 4.6 \\
\hline MD & & 5.9 & 0.3 & 0.5 \\
\hline Professional & & 24.3 & 46.4 & 45.5 \\
\hline MBA & & 20.7 & 38.3 & 34.1 \\
\hline JD & & 3.6 & 8.0 & 11.5 \\
\hline Master's & & 14.8 & 16.1 & 16.1 \\
\hline \multicolumn{5}{|l|}{ Undergraduate major } \\
\hline Engineering & & 32.2 & & \\
\hline Business & & 30.1 & & \\
\hline Science (phys., bio., chem., math) & & 25.0 & & \\
\hline Other & & 12.7 & & \\
\hline
\end{tabular}

\footnotetext{
${ }^{21}$ On average, firms disclosing policy amounts are very similar to those that insure but do not list policy amounts (unreported).
} 
of key employees identified in the filings. These data are collected by searching www.nndb.com for each individual listed as an insured key employee. ${ }^{22}$ There are 1,171 key employees listed in company filings for our sample. Of these, we identify the title/position of the employee, the graduate educational background, and the undergraduate major for $58 \%, 37 \%$, and $25 \%$ of these individuals, respectively.

Over two-thirds of the key employees hold the position of CEO, and approximately one-third are founders. Many are also scientists and researchers. Several individuals hold the position of chief scientist, and over $65 \%$ have a graduate degree. A large percentage of the key employees also have technical undergraduate degrees, with $32 \%$ having an engineering degree and $25 \%$ majoring in a hard science during their undergraduate years.

Although these numbers appear to support the notion that the key employees we identify are highly educated, it is informative to compare these disclosed key employees with another set of important employees: executives of large U.S. public companies. By merging the ExecuComp and BoardEx databases, we obtain education background data for 2,548 CEOs and 10,671 of the top 5 paid executives of firms covered by ExecuComp (roughly the Standard \& Poor's (S\&P) 1500) from 1997 to 2010 . When we compare the degrees of key employees with those of the full sample of ExecuComp CEOs and top 5 earners, we find that a similar number of executives have graduate degrees. However, the types of graduate degrees differ between the two groups. Over $45 \%$ of executives hold the professional degrees of MBA and JD, whereas only $24 \%$ of key employees hold these degrees. More striking is that $26 \%$ of key employees hold either a $\mathrm{PhD}$ or MD, whereas only $5 \%-6 \%$ of executives do. Taken together, these findings suggest that those identified as key employees possess substantial human capital and that the type of human capital that they possess is much different from that of the typical executive.

\section{Key-Human-Capital-Intensive Firms}

In this section, we further investigate the characteristics of firms that are exposed to key human capital risk. We then investigate differences in firms that choose to insure their key employees and those that do not.

\section{A. Determinants of Key Human Capital}

Table 3 displays the marginal effects and their standard errors clustered by firm for probit regressions, where the dependent variable is KEY_HUMAN_CAPITAL, and the independent variables include lagged firm characteristics. In all specifications, we include year fixed effects because Figure 2 shows a clear upward time trend in the probability of firms making key man insurance disclosures. Where indicated, regressions include industry fixed effects based on the Fama-French (1997) 48 industry classifications.

\footnotetext{
${ }^{22}$ www.nndb.com is an online resource that lists personal information about "notable" people. The database includes information on educational background, work experience, and general biographical information and covers approximately 100,000 individuals.
} 
TABLE 3

Determinants of Key Human Capital

\begin{tabular}{|c|c|c|c|c|c|c|}
\hline & \multicolumn{6}{|c|}{ Dependent Variable: KEY_HUMAN_CAPITAL } \\
\hline & 1 & 2 & 3 & 4 & 5 & 6 \\
\hline In(REAL_ASSETS) & $\begin{array}{l}-0.0271^{\star \star \star} \\
(0.0029)\end{array}$ & $\begin{array}{l}-0.0309^{\star \star \star} \\
(0.0030)\end{array}$ & $\begin{array}{l}-0.0113^{\star *} \\
(0.0048)\end{array}$ & $\begin{array}{r}-0.0098^{\star} \\
(0.0052)\end{array}$ & $\begin{array}{l}-0.0169^{\star \star \star \star} \\
(0.0049)\end{array}$ & $\begin{array}{l}-0.0126^{\star \star *} \\
(0.0044)\end{array}$ \\
\hline FIRM_AGE & $\begin{array}{l}-0.0060^{\star \star \star} \\
(0.0005)\end{array}$ & $\begin{array}{l}-0.0052^{\star \star \star} \\
(0.0005)\end{array}$ & $\begin{array}{l}-0.0026^{\star \star \star} \\
(0.0004)\end{array}$ & $\begin{array}{l}-0.0034^{\star \star \star} \\
(0.0004)\end{array}$ & $\begin{array}{l}-0.0030^{* \star \star} \\
(0.0005)\end{array}$ & $\begin{array}{l}-0.0022^{* * *} \\
(0.0004)\end{array}$ \\
\hline Q & $\begin{array}{l}0.0047^{\star \star \star} \\
(0.0015)\end{array}$ & $\begin{array}{l}0.0051^{\star \star \star} \\
(0.0014)\end{array}$ & $\begin{array}{c}0.0031 \\
(0.0023)\end{array}$ & $\begin{array}{c}0.0032 \\
(0.0021)\end{array}$ & $\begin{array}{c}0.0017 \\
(0.0019)\end{array}$ & $\begin{array}{l}0.0010 \\
(0.0017)\end{array}$ \\
\hline TANGIBILITY & $\begin{array}{l}-0.0586^{\star \star \star} \\
(0.0129)\end{array}$ & $\begin{array}{l}-0.0848^{\star \star \star} \\
(0.0141)\end{array}$ & $\begin{array}{r}-0.0330^{*} \\
(0.0193)\end{array}$ & $\begin{array}{c}-0.0471^{* *} \\
(0.0219)\end{array}$ & $\begin{array}{c}-0.0505^{* *} \\
(0.0216)\end{array}$ & $\begin{array}{l}-0.0533^{* * *} \\
(0.0206)\end{array}$ \\
\hline R\&D_INTENSITY & $\begin{array}{l}0.0018 \\
(0.0022)\end{array}$ & $\begin{array}{c}0.0004 \\
(0.0021)\end{array}$ & $\begin{array}{c}0.0052 \\
(0.0047)\end{array}$ & $\begin{array}{l}0.0191^{\star \star} \\
(0.0081)\end{array}$ & $\begin{array}{l}0.0135^{\star *} \\
(0.0063)\end{array}$ & $\begin{array}{c}0.0094 \\
(0.0086)\end{array}$ \\
\hline LEVERAGE & $\begin{array}{r}0.0333^{\star} \\
(0.0190)\end{array}$ & $\begin{array}{l}0.0493^{\star \star \star} \\
(0.0185)\end{array}$ & $\begin{array}{c}-0.0117 \\
(0.0220)\end{array}$ & $\begin{array}{c}-0.0353 \\
(0.0262)\end{array}$ & $\begin{array}{c}-0.0176 \\
(0.0262)\end{array}$ & $\begin{array}{c}-0.0368 \\
(0.0271)\end{array}$ \\
\hline VC_BACKED_IPO & $\begin{array}{c}0.0075 \\
(0.0114)\end{array}$ & $\begin{array}{c}0.0007 \\
(0.0112)\end{array}$ & $\begin{array}{c}0.0058 \\
(0.0129)\end{array}$ & $\begin{array}{c}0.0048 \\
(0.0139)\end{array}$ & $\begin{array}{c}0.0058 \\
(0.0142)\end{array}$ & $\begin{array}{c}0.0048 \\
(0.0123)\end{array}$ \\
\hline In(NUMBER_OF_8K_FILINGS) & $\begin{array}{l}0.0351^{\star \star \star} \\
(0.0042)\end{array}$ & $\begin{array}{l}0.0324^{\star \star \star} \\
(0.0041)\end{array}$ & $\begin{array}{r}0.0076^{\star} \\
(0.0045)\end{array}$ & $\begin{array}{l}0.0109^{\star \star} \\
(0.0048)\end{array}$ & $\begin{array}{c}0.0044 \\
(0.0049)\end{array}$ & $\begin{array}{l}0.0123^{\star \star} \\
(0.0053)\end{array}$ \\
\hline SG\&A (lag 1) & $\begin{array}{c}0.0100 \\
(0.0143)\end{array}$ & $\begin{array}{c}-0.0166 \\
(0.0147)\end{array}$ & $\begin{array}{c}-0.0143 \\
(0.0230)\end{array}$ & $\begin{array}{c}0.0020 \\
(0.0268)\end{array}$ & $\begin{array}{c}-0.0065 \\
(0.0245)\end{array}$ & $\begin{array}{c}0.0064 \\
(0.0230)\end{array}$ \\
\hline G_INDEX & & & $\begin{array}{l}-0.0027 \\
(0.0020)\end{array}$ & & & \\
\hline PROP_OF_BOARD_IND & & & & $\begin{array}{c}-0.0495^{\star \star} \\
(0.0248)\end{array}$ & & \\
\hline CEO_GENERAL_ABILITY_INDEX & & & & & $\begin{array}{c}0.0000 \\
(0.0052)\end{array}$ & \\
\hline CEO_IS_COMPANY_FOUNDER & & & & & & $\begin{array}{l}0.0353^{* *} \\
(0.0145)\end{array}$ \\
\hline $\begin{array}{l}\text { Time fixed effects } \\
\text { Industry fixed effects }\end{array}$ & $\begin{array}{l}\text { Yes } \\
\text { No }\end{array}$ & $\begin{array}{l}\text { Yes } \\
\text { Yes }\end{array}$ & $\begin{array}{l}\text { Yes } \\
\text { Yes }\end{array}$ & $\begin{array}{l}\text { Yes } \\
\text { Yes }\end{array}$ & $\begin{array}{l}\text { Yes } \\
\text { Yes }\end{array}$ & $\begin{array}{l}\text { Yes } \\
\text { Yes }\end{array}$ \\
\hline $\begin{array}{l}\text { Pseudo- } R^{2} \\
N \\
\text { Prob. of dependent variable }\end{array}$ & $\begin{array}{c}0.10 \\
49,308 \\
0.19\end{array}$ & $\begin{array}{c}0.13 \\
48,581 \\
0.20\end{array}$ & $\begin{array}{c}0.17 \\
12,598 \\
0.12\end{array}$ & $\begin{array}{c}0.17 \\
13,708 \\
0.12\end{array}$ & $\begin{array}{c}0.18 \\
11,564 \\
0.12\end{array}$ & $\begin{array}{l}0.21 \\
7,274 \\
0.11\end{array}$ \\
\hline
\end{tabular}

The results in columns 1 and 2 of Table 3 are mostly consistent with those of the earlier unconditional tests. Smaller, younger firms with better growth opportunities, lower asset tangibility, and greater propensity to make disclosures are more likely to be key human capital intensive. Although most of these findings are fairly intuitive, finding that key human capital is positively related to the propensity to disclose shows the importance of controlling for this disclosure effect later when investigating firm risk. Interestingly, the ratio of SG\&A to total assets is not related to KEY_HUMAN_CAPITAL. Although this measure of training should matter for the human capital of rank-and-file employees, the regression shows that it is not important for key employees. ${ }^{23}$

\footnotetext{
${ }^{23}$ Of course, SG\&A is included in the regression, not accumulated SG\&A, but SG\&A is generally highly autocorrelated, so 1 lag is a fairly good proxy for accumulated SG\&A. Including 3 lags in this regression does not change this result.
} 
It is possible that governance plays a role in whether firms make key man life insurance disclosures. We test this possibility in columns 3 and 4 of Table 3 by including two measures of governance. In column 3, we include the G-Index of Gompers, Ishii, and Metrick (2003), and in column 4, we include the proportion of independent directors on the board. Coverage for these data is limited to roughly the S\&P 1500, so these regressions include only larger firms. Although the G-Index is not significantly related to key human capital, firms with fewer independent board members are more likely to have key human capital. This could be indicative of firms with key human capital having weaker corporate governance, or it could be because firms with key human capital have a greater need for firm-specific knowledge, so having fewer outside board members is optimal.

Finally, we test whether characteristics firms' CEOs are related to key human capital. Again, the coverage of these characteristics is limited to the subset of large firms. In these conditional tests, the GAI of the CEO is unrelated to key human capital, but firms run by founder CEOs are more likely to have key human capital. Adams et al. (2005) find that firms with powerful CEOs are more risky. The authors' most robust measure of powerful CEOs is a CEO founder indicator variable. Thus, it will be important to control for this finding when we test whether firms with key human capital are more risky. ${ }^{24}$

\section{B. The Decision to Insure Key Employees}

Although firms can insure death using key man insurance policies, they are unable to insure the turnover of their key employees, which is a much more likely and potentially destructive event. We next investigate the decision to purchase life insurance on key employees. We do so by estimating a probit regression where the dependent variable is INSURE_KEY_EMPLOYEE within the set of firms with key human capital. Results are presented in Table 4. The determinants investigated are identical to those investigated in Table 3.

The specifications in columns 1 and 2 of Table 4 using the full sample of firms with key human capital show that insuring firms are slightly smaller, have worse growth opportunities, and have even fewer tangible assets than similar firms with key human capital who choose not to insure the lives of their key employees. Not surprisingly, there is no difference in the insuring firms' propensity to make disclosures compared with noninsuring firms.

When governance variables are added to the regressions, there is no significant relationship. CEO characteristics are, however, related to purchasing insurance. Firms with CEOs with more firm-specific skills are more likely to purchase insurance. If the skill set of the CEO is positively correlated with that of the key employee, then this would suggest that key employees whose skills are more difficult to replace are more likely to be insured. Founders also may hold firm-specific knowledge that is particularly difficult to replace. Consistent with this, companies

\footnotetext{
${ }^{24}$ Panel A of Table IA.1 in the Internet Appendix (available at www.jfqa.org) shows results of similar probit regressions where INSURE_KEY_EMPLOYEE is the dependent variable. The results are very similar to those in Table 3; however, insuring firms do not have better growth opportunities than other firms, and their CEOs' human capital tends to be more firm specific.
} 
TABLE 4

The Decision to Insure Key Employees

Table 4 displays the marginal effects and their standard errors clustered at the firm level for probit regressions where the dependent variable INSURE KEY EMPLOYEE, which is an indicator variable that is equal to 1 if the firm discloses that it holds key man life insurance, and 0 otherwise. Control variables are lagged by 1 year unless noted otherwise, and definitions are included in Appendix $C$. The sample includes the panel of all nonfinancial firms traded on the NYSE/NASDAQ/AMEX from 1997-2009 that disclose whether or not they insure key employees. Specifications that include industry fixed effects use the Fama-French (1997) 48 industries. * ${ }^{* *}$, and ${ }^{\star * \star}$ indicate significance at the $10 \%, 5 \%$, and $1 \%$ levels, respectively.

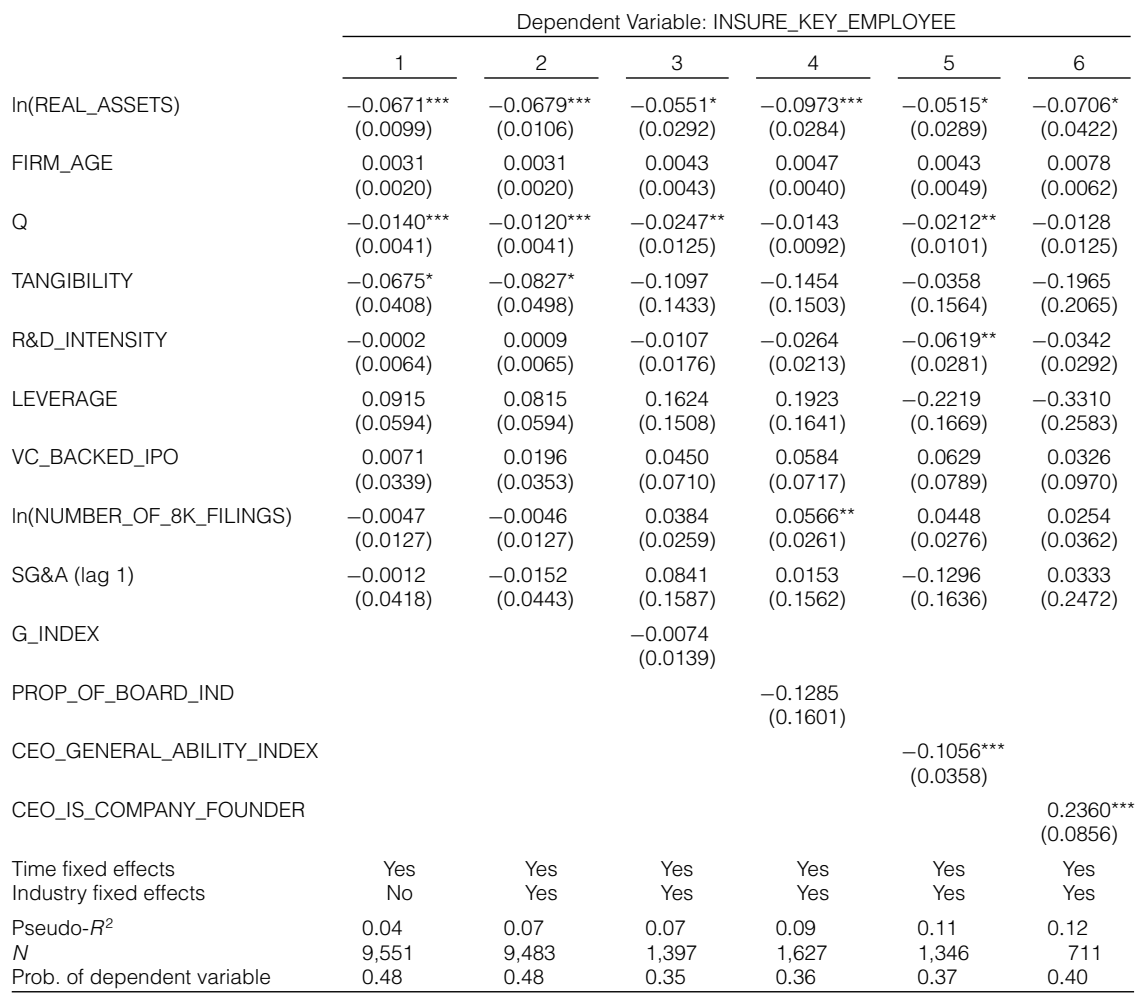

whose CEOs are founders are much more likely to hold insurance on their key employees. ${ }^{25}$

\section{Is Key Human Capital Risky?}

In this section, we test whether firms with key human capital are more risky than their counterparts. We address this question in two ways: generally and specifically. First, we examine whether volatility is generally higher for firms with key human capital. Second, we focus on a specific event that is likely to be the

${ }^{25}$ Panel B of Table IA. 1 in the Internet Appendix shows the results of similar ordinary least squares (OLS) regressions where KEY_HUMAN_CAPITAL_INTENSITY is the dependent variable. Smaller firms with better growth opportunities, lower asset tangibility, and greater expenditure on SG\&A and that have fewer independent board members and were not backed by VC at the time of their IPOs have greater key human capital intensity. Within this set of disclosing firms, there is no difference in the propensity to make voluntary disclosures. 
primary source of the key human capital risk (the unanticipated, voluntary departure of a key employee) and examine abnormal returns.

\title{
A. Volatility and Key Human Capital
}

To test whether key-human-capital-intensive firms are more risky, we regress total and firm-specific volatility on lagged KEY_HUMAN_CAPITAL and other determinants of volatility along with year and industry fixed effects. We define volatility as the sample standard deviation of daily returns and idiosyncratic volatility as the sample standard deviation of residuals from a regression of excess daily returns on the 3 Fama-French (1993) factors. Each measure uses daily returns during the calendar year. If firms exposed to key human capital risk are riskier than their peers, then the coefficient estimate on KEY_HUMAN_CAPITAL should be positive. Panel A of Table 5 provides the results.

In column 1 of Table 5, we regress volatility on KEY_HUMAN_CAPITAL, along with time and industry fixed effects. The coefficient estimate on

\section{TABLE 5}

\section{Risk and Key Human Capital}

\begin{abstract}
Panel A of Table 5 displays the coefficient estimates and their standard errors clustered at the firm level for linear regressions of two different measures of volatility on measures of key human capital and various firm characteristics. STOCK_VOLATILITY is the daily standard deviation of stock returns. STOCK_IDIOSYNCRATIC_VOLATILITY is the standard deviation of the residual from a regression of daily stock returns on the 3 Fama-French (1993) factors. KEY_HUMAN_CAPITAL is an indicator variable that is equal to 1 if the firm discloses whether it carries key man life insurance, and 0 otherwise. INSURE_KEY_EMPLOYEE is a dummy variable that is equal to 1 if the firm discloses that it carries key man insurance, and 0 otherwise. KEY_HUMAN_CAPITAL_INTENSITY is total key man insurance policy amounts to total assets. All explanatory variables are lagged by 1 year unless noted otherwise, and definitions are included in Appendix $C$. The sample includes the panel of all nonfinancial firms traded on the NYSE/NASDAQ/AMEX from 1998 to 2010. Industry fixed effects use the Fama-French (1997) 48 industries. Panel B includes additional governanceand CEO-related explanatory variables. Panel $\mathrm{C}$ shows the average difference between firms with key human capital (KEY_HUMAN_CAPITAL = 1) and two different matched samples. In the first row, the matched sample is constructed using a propensity score nearest-neighbor approach without replacement based on In(REAL_ASSETS), FIRM_AGE, Q, TANGIBILITY, R\&D_INTENSITY, LEVERAGE, VC_BACKED_IPO, SG\&A, and In(NUMBER_OF_8K_FILINGS). Propensity scores are estimated for each year in the panel, and neighbors are chosen during the same year. The second matched sample follows a similar algorithm with one additional constraint. The control observation is chosen from the same FamaFrench (1997) 48 industries as the treated observation. *, **, and *** indicate significance at the $10 \%, 5 \%$, and $1 \%$ levels, respectively.
\end{abstract}

Panel A. Full Sample

\section{KEY_HUMAN_CAPITAL}

INSURE_KEY_EMPLOYEE

KEY_HUMAN_CAPITAL_INTENSITY

$\ln ($ REAL_ASSETS)

FIRM_AGE

Q

TANGIBILITY

R\&D_INTENSITY

LEVERAGE

VC_BACKED_IPO
Dependent Variable: STOCK_VOLATILITY

\begin{tabular}{|c|c|c|c|}
\hline 1 & 2 & 3 & 4 \\
\hline \multirow[t]{2}{*}{$\begin{array}{l}0.80^{\star \star \star \star} \\
(0.06)\end{array}$} & $\begin{array}{l}0.20^{\star \star \star} \\
(0.04)\end{array}$ & $\begin{array}{l}0.17^{\star \star \star \star} \\
(0.05)\end{array}$ & \\
\hline & & $\begin{array}{c}0.07 \\
(0.07)\end{array}$ & \\
\hline
\end{tabular}

$1.07^{\star \star *}$

(0.38)

$-0.81^{\star \star \star}$

(0.06)

$-0.02^{\star}$
$(0.01)$

$-0.26^{\star \star \star}$

$(0.03)$

0.20

$(0.23)$

$0.13^{\star \star \star}$

$0.13^{\star \star \star}$
$(0.03)$

$(0.03)$
$1.95^{\star \star \star}$

(0.33)

$-0.15$

(0.16)
Dependent Variable: STOCK_IDIOSYNCRATIC_VOLATILITY

\begin{tabular}{|c|c|c|c|}
\hline 5 & 6 & 7 & 8 \\
\hline \multirow[t]{2}{*}{$\begin{array}{l}0.83^{\star \star \star} \\
(0.06)\end{array}$} & $\begin{array}{l}0.19^{\star \star \star \star} \\
(0.04)\end{array}$ & $\begin{array}{l}0.16^{\star \star \star} \\
(0.05)\end{array}$ & \\
\hline & & $\begin{array}{c}0.06 \\
(0.07)\end{array}$ & \\
\hline
\end{tabular}

$1.08^{\star \star *}$
$(0.38)$

$-0.68^{\star \star \star} \quad-0.68^{\star \star \star} \quad-0.91^{\star \star \star}$

$\begin{array}{lll}(0.01) & (0.01) \quad(0.06)\end{array}$

$-0.01^{\star \star \star} \quad-0.01^{\star \star \star} \quad-0.02^{\star}$

$\begin{array}{lll}(0.00) & (0.00) \quad(0.01)\end{array}$

$-0.16^{\star \star \star} \quad-0.16^{\star \star \star} \quad-0.30^{\star \star \star}$

$\begin{array}{lll}(0.01) & (0.01) \quad(0.03)\end{array}$

$-0.20^{\star \star \star} \quad-0.20^{\star \star \star} \quad 0.25$

$\begin{array}{lll}0.06) & (0.06) \quad(0.23)\end{array}$

$0.13^{\star \star \star} \quad 0.13^{\star \star \star} \quad 0.13^{\star \star \star}$

$\begin{array}{lll}0.13^{\star \star \star} & 0.13^{\star \star \star} & 0.13^{\star \star *} \\ (0.03) & (0.03) & (0.03)\end{array}$

$2.26^{\star \star \star}-2.26^{\star \star \star} \quad 2.05^{\star \star \star}$

$\begin{array}{lll}(0.09) & (0.09) \quad(0.32)\end{array}$

$0.15^{\star \star \star} \quad 0.15^{\star \star \star} \quad-0.12$

$\begin{array}{lll}0.15 & (0.04) & (0.15)\end{array}$

(continued on next page) 
TABLE 5 (continued)

Risk and Key Human Capital

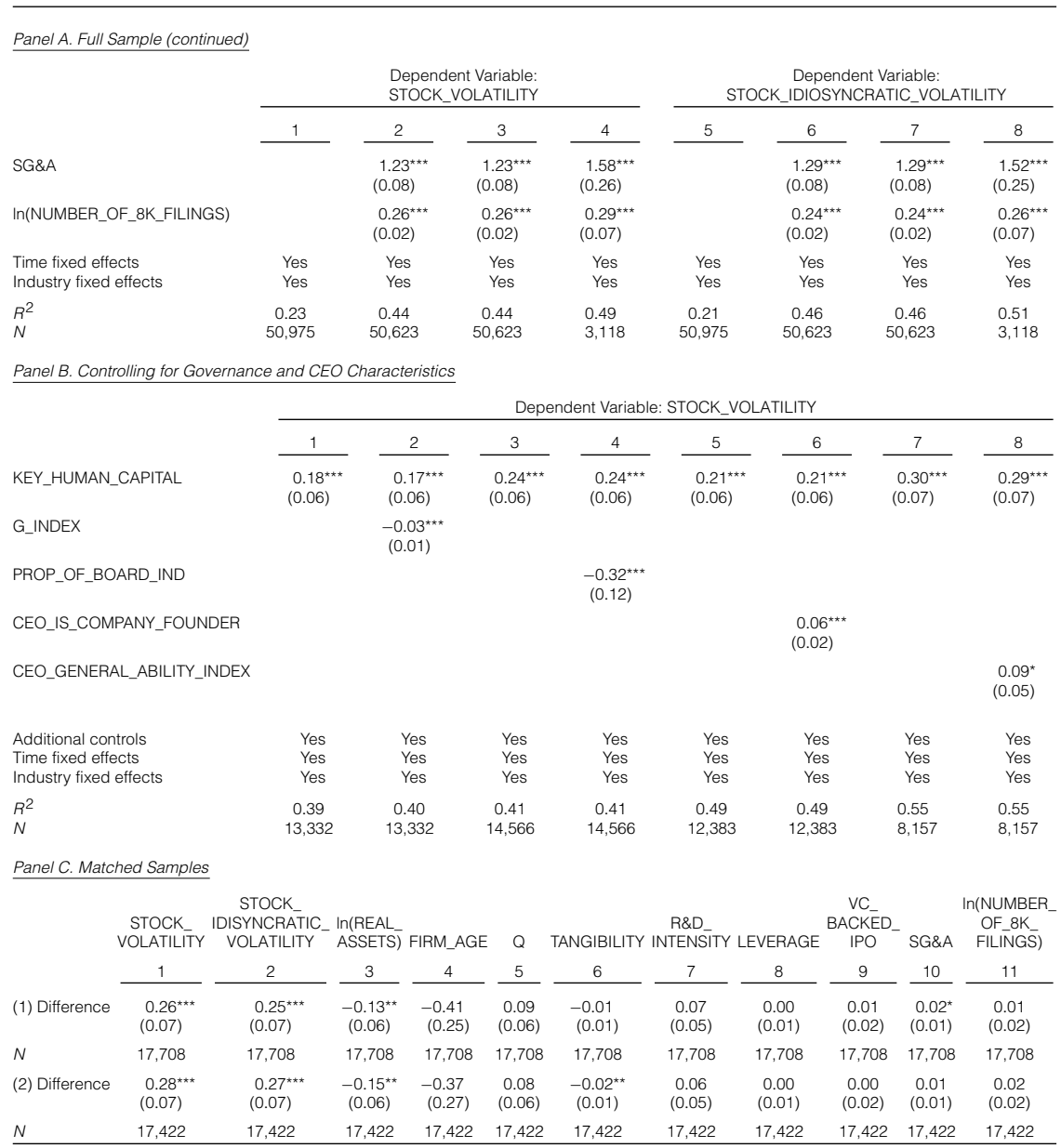

KEY_HUMAN_CAPITAL is 80 basis points (bps) and is statistically significant at the $1 \%$ level. In economic terms, this represents a volatility approximately $19 \%$ higher than that of firms that do not make key man insurance disclosures. Because some firms may carry key man insurance policies to satisfy a loan covenant, it is possible that financial constraints rather than key human capital may be the ultimate source of the volatility. To rule out this alternative, we control for variables associated with financial constraints. In column 2 , we add these additional firmspecific lagged control variables to the model estimated in column 1 . This addition nearly doubles the explanatory power of the regression, and the estimates on each of the controls are statistically significant. Nonetheless, the coefficient estimate on KEY_HUMAN_CAPITAL is 20 bps and is significant at better than the $1 \%$ level. This indicates that firms exposed to key human capital risk are approximately $5 \%$ 
more risky than industry peers with similar characteristics, controlling for financial constraints.

By comparison, the economic significance of KEY_HUMAN_CAPITAL on risk is similar to that of many of the other firm characteristics. For instance, both VC backing during the firm's IPO and a 1-standard-deviation decrease in growth opportunities are associated with similar increases in volatility as the presence of key human capital. The most economically important firm characteristics for risk are firm size and leverage; 1-standard-deviation increases in these variables lead to $-28 \%$ and $11 \%$ changes in volatility, respectively. Using the same metric, examples of characteristics with smaller economic impact on volatility than key human capital include R\&D intensity and asset tangibility.

We next examine whether firms that disclose that they carry insurance on key employees are more risky than those that choose not to insure their key employees. If financial constraints are to blame for the volatility, risk should differ based on whether firms carry insurance in order to increase access to capital. Because firms that insure key employees are a subset of KEY_HUMAN_CAPITAL, we include both indicator variables in the regression in column 3 of Table 4. The coefficient estimate on INSURE_KEY_EMPLOYEE is the incremental increase or decrease in risk associated with insuring key employees. The regression indicates that there is no statistically significant difference in the level of risk between exposed firms that choose to insure and those that do not. This suggests that hedging the death of key employees does little to reduce the major risk to firms posed by their key employees: voluntary departure. Furthermore, it also provides evidence that what matters for risk is the disclosure of key man insurance and not whether a firm actually carries a policy.

Recall that key human capital risk should be greatest in firms with more concentrated key human capital stocks. In column 4 of Table 4 , we test this within the set of firms exposed to key human capital risk. In order to do so, we replace KEY_HUMAN_CAPITAL with KEY_HUMAN_CAPITAL_INTENSITY in the regression. If firms with greater exposure to key human capital risk are riskier, then the coefficient estimate on KEY_HUMAN_CAPITAL_INTENSITY should be positively estimated. The coefficient estimate on KEY_HUMAN_ CAPITAL_INTENSITY is 1.09 and is significant at better than the $1 \%$ level. The estimates suggest that a 1-standard-deviation increase in key human capital intensity (0.19) increases firm risk by approximately 21 bps or approximately $5 \%$ of the average volatility of firms exposed to key human capital risk.

In the next four columns of Table 4, we repeat the same regressions, replacing the dependent variable with our measure of idiosyncratic volatility. The results are very similar and tend to be slightly larger in magnitude. Taken together, these results suggest that i) firms with key human capital are riskier, in terms of both total risk and idiosyncratic risk; ii) there is no difference in risk between firms that insure key employees and those that do not; and iii) within the set of firms exposed to key human capital risk, those with greater exposure are more risky.

In our previous analysis, we found differences in governance and CEO characteristics across firms with and without key human capital. We may be worried that these differences are driving our results. For instance, Adams et al. (2005) show that firms with founder CEOs have greater volatility. Because data on these 
variables are available for only a limited sample of firms, in Panel B of Table 5 we show two regressions for each additional control variable: one including only the observations for which the additional control variable is available and one including the additional control. This allows us to observe the incremental effect of including the additional control variable on the coefficient estimate of KEY_HUMAN_CAPITAL. Although we corroborate the results of Adams et al. (2005) that firms with founder CEOs have higher volatility, the results show almost no effect of including any of the additional control variables on our coefficient estimates on KEY_HUMAN_CAPITAL. In addition, the economic significance of each of these additional controls is much smaller than that of key human capital.

As we showed earlier in Table 3, firms exposed to key human capital risk differ substantially from unexposed firms in ways other than just governance and CEO characteristics. Moreover, firms choose whether to disclose whether they carry key man policies. It could be that riskier firms choose to make key man insurance disclosures and not that key human capital risk makes firms risky. To alleviate this concern, in Panel $\mathrm{C}$ of Table 5 we test for differences in risk taking between firms that are exposed to key human capital risk ("KEY_HUMAN_CAPITAL $=1$ ") and two different matched samples based on propensity score matching. In the first row, the matched sample is constructed using a propensity score nearest-neighbor approach by choosing a single match without replacement ${ }^{26}$ based on $\ln ($ REAL_ASSETS), FIRM_AGE, Q, TANGIBILITY, R\&D_INTENSITY, LEVERAGE, VC_BACKED, SG\&A, and ln(NUMBER_OF_8K_FILINGS). Propensity scores are estimated for each year in the panel, and neighbors are chosen during the same year. The second matched sample follows a similar algorithm, with one additional constraint. Each matched observation is chosen from the same Fama-French (1997) 48 industries as the exposed observation.

The results of the analysis are reported in Panel $\mathrm{C}$ of Table 5. The difference in volatility and idiosyncratic volatility between firms exposed to key human capital risk and the unexposed matched firms is between 25 bps and 28 bps, which is consistent with the findings in Panel A. The table also reports these differences for all of the matching characteristics. In general, the unexposed matched firms are very similar along most dimensions to the firms exposed to key human capital risk. Statistically, there are some small differences in the characteristics of these samples; however, when compared with the differences between exposed and unexposed firms presented in Table 1, these differences are economically small.

This section provides strong evidence on the impact of key human capital on firm risk in the cross section. An alternative approach involves testing for the effect using within-firm variation. However, there are several challenges to such an approach. First, there is very little within-firm variation in key human capital. A within-firm estimator would be relying on variation in only approximately $3.5 \%$ of firms. Second, timing is crucial for within-firm estimation. As we describe in

\footnotetext{
${ }^{26}$ We choose to construct our matched sample with a single match without replacement because this should lead to the most precisely matched sample. Roberts and Whited ((2013), p. 74) note that "using a single match leads to the least biased and most credible estimates."
} 
Section II, the timing of our key human capital measures is not exact, largely because of the involuntary nature of these disclosures. To address these issues, we perform a targeted within-firm analysis by examining cumulative stock returns around the announcement of key employee voluntary departure, which is one of the biggest risks associated with key human capital. For this experiment, the timing is precise, and the hypothesis on stock returns is clear: Stock prices should fall on the announcement.

\section{B. Event Study}

The primary role of a key man insurance policy is to hedge a firm against the risk of losing key human capital due to untimely death. However, if the human capital associated with a covered employee is difficult or costly to replace, there is still a risk associated with voluntary departure. We test this hypothesis by examining the reaction of a firm's stock price around the announcement of the departure of key employees. If the market believes that the human capital represented by the departing employee will be difficult or impossible to replace, there should be a significant negative stock return when the news is made public. Alternatively, if the market believes the human capital associated with the employee will be relatively easy to replace, there should be very little reaction to the news.

There is a well-established body of literature on the financial implications of executive turnover. Studies examining shareholder wealth effects around executive departures vary on two dimensions: the type of executive and the nature of the turnover. Most studies focus on the CEO. Abnormal returns are generally positive following news of a death ${ }^{27}$ and mixed around news of a departure. ${ }^{28}$ However, not all executives are irreplaceable, and not all irreplaceable employees are executives; thus, we examine the turnover of only those employees most likely to possess firm-specific human capital: key employees.

We begin with the sample of 1,171 employees we identified as subjects of key man life insurance policies. For each employee covered by a key man policy, we search through the Dow Jones Factiva database and a variety of public news sources to determine when (if ever) he or she departed the position at his or her firm, and we determine the earliest date that this information was made public. This leaves us with 244 potential events with clear announcement dates. In 73 of

\footnotetext{
${ }^{27}$ Johnson et al. (1985) find a positive but insignificant share price reaction to the announcement of 53 CEO deaths. Borokhovich et al. (2006) find significantly positive abnormal returns following 161 executive sudden deaths.

${ }^{28}$ Warner et al. (1988) exclude death and find no significant response to news of 279 topmanagement changes or 92 CEO changes. Denis and Denis (1995) examine announcement period returns for 328 changes in CEOs (Denis and Denis also include the chairman of the board if there is no CEO) and 525 changes in other top executives from 1985 to 1988 and find either insignificant or positive returns at the announcement date for forced resignations, for normal retirements, and for all changes. The only study to find evidence of a negative relationship between shareholder wealth and executive turnover is that of Hayes and Schaefer (1999), who find cumulative abnormal returns of $-0.62 \%$ from the day before to the day after the announcements of 129 CEOs and non-CEOs who leave to join other firms. However, the returns are not statistically significant at the 5\% level, and most of the return comes the day before the announcement, which makes it difficult to disentangle whether the executive is departing due to bad news or whether the market is reacting to the news of the executive departure.
} 
these cases, the executive either accepted another position at the firm or continued to consult with the firm. Because we are interested in the risk that the human capital is lost to the firm, we exclude these events. We also remove from our sample the 76 events that we determine to be forced resignations or deaths. Next, we remove 30 events that coincide with another major corporate announcement (e.g., the release of quarterly earnings, the announcement of a merger, or a major product release). Finally, we remove from the sample employees from 5 firms whose stocks prices are under $\$ 1$ at the time of the announcement. This leaves us with 60 observations to use in our event study.

We calculate abnormal returns using both the CAPM and the Fama-French (1993) 3-factor model (FF3). First, we estimate factor loadings using stock returns from 250 to 30 trading days before the announcement date. Next, we use these factor loadings to estimate the abnormal return on the trading day before the event, the day of the event (or the next trading day if the announcement was made on a weekend or a holiday), and the 4 trading days following the event. Figure 3 displays the CARs as well as the $95 \%$ confidence interval for days -1 through 4 using the FF3 model. There is a distinct $2.34 \%$ drop in abnormal returns on the day of the announcement. By day 2, the CAR is $-3.47 \%$, which drops to $-4.20 \%$ by day 4. All CARs from days $0-4$ are statistically significant. The results are similar when using the CAPM to adjust returns.

There is a large variation in the amount of key human capital represented by these departing employees, with policy amounts ranging between $\$ 144$ thousand and $\$ 12$ million. A defining feature of key human capital risk is that the greater

\section{FIGURE 3}

Key Employee Departure Announcement Returns

Figure 3 displays the average CARs around the announcement of the departure from the firms of 60 key employees. Abnormal returns are calculated using the FF3 (Fama and French (1993)). Factor loadings are estimated using returns from trading days 250 to 30 days before the announcement. Events take place between 1997 and 2011. The dashed lines indicate the $95 \%$ confidence bands.

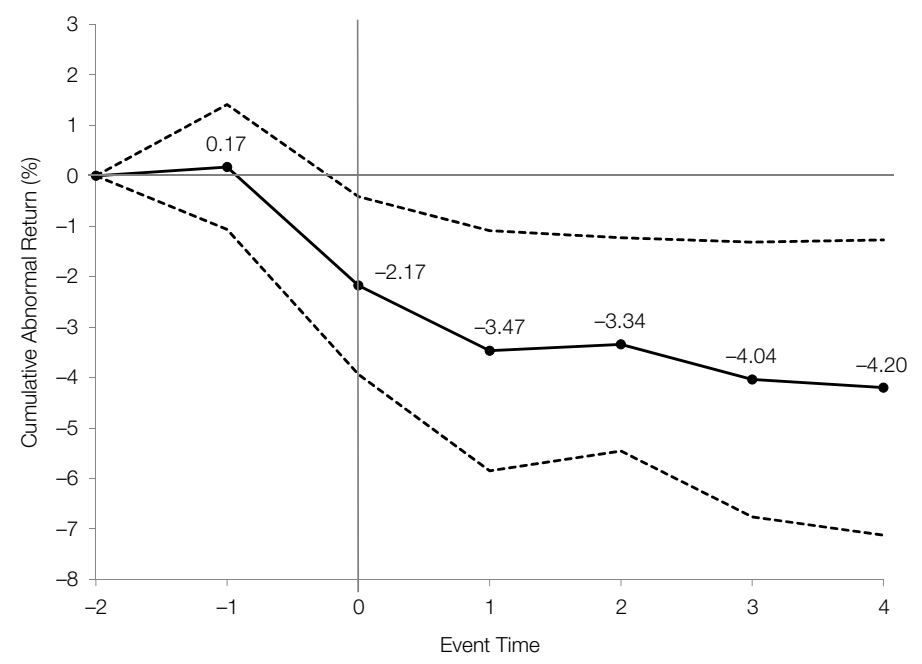


the concentration, the greater the risk. Thus, all else equal, we expect firms with larger KEY_HUMAN_CAPITAL_INTENSITY to be more impacted when these key employees depart. To test this, we divide firms into two groups based on key human capital intensity (KHC). High KHC denotes firms whose KHC is above median, and Low KHC denotes firms whose $\mathrm{KHC}$ is below median. Sorts are performed each year using all firms with nonmissing KHC.

Figure 4 displays the CARs for both the High KHC and Low KHC firms. As shown in Figure 4, 28 executive departures were from High KHC firms, and 29 were from Low KHC firms. ${ }^{29}$ The average $\mathrm{KHC}$ for the high and low groups is $14.58 \%$ and $1.8 \%$, respectively. The results from this analysis confirm our suspicions. When key executives leave High $\mathrm{KHC}$ firms, average CARs drop by roughly $4 \%$, reach $-7 \%$ by the following day, and are close to $-8 \%$ by 4 days after the event. These numbers are statistically significant from the event day forward and are roughly twice as large as the overall averages from Figure 3. Accordingly, when key executives depart from Low KHC firms, there is little effect. There is a small drop on the announcement date, but CARs are never statistically different from 0 .

As mentioned in the Introduction, it is possible that key employees depart in anticipation of bad news and that the market rationally infers this. If so, the

FIGURE 4

Key Employee Departure Announcement Returns by KHC

Figure 4 displays the average CARs around the announcement of the departure from firms of key employees for firms categorized into groups with high and low key human capital intensity (KHC) based on median KHC during the departure year. KHC is defined as the total value of a firm's key man life insurance policies scaled by its total book value of assets. There are 28 and 29 key employee departures for the High and Low KHC firms, respectively. Abnormal returns are calculated using the Fama-French (1993) 3-factor model. Factor loadings are estimated using returns from trading days 250 to 30 days before the announcement. The 57 events take place between 1997 and $2011 .{ }^{* *}$ and ${ }^{* \star *}$ indicate significance at the $5 \%$ and $1 \%$ levels, respectively.

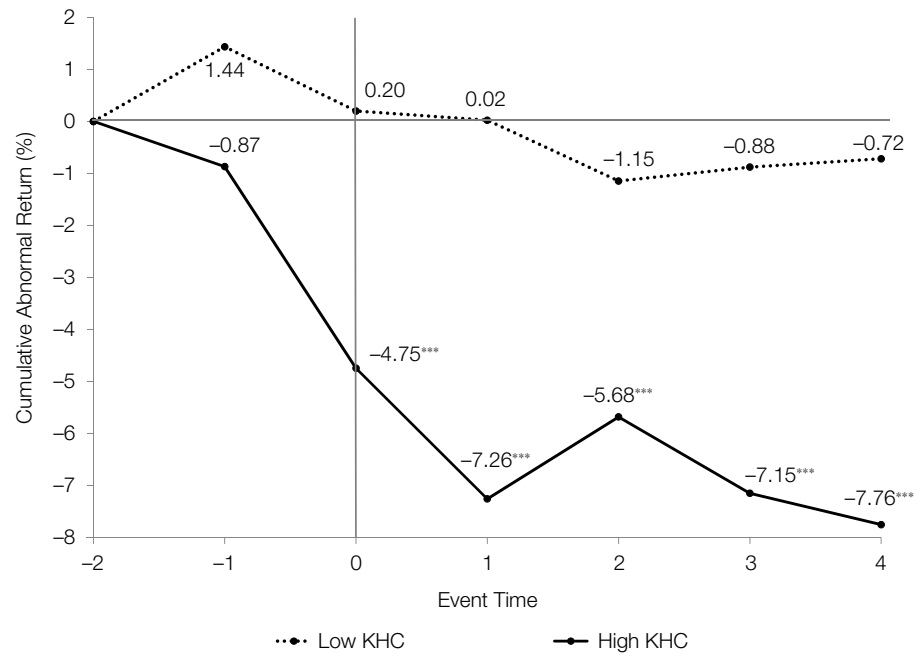

\footnotetext{
${ }^{29}$ The three missing observations result from firms that disclosed that the individual was the subject of a key man insurance policy but did not disclose the policy amount.
} 
negative announcement returns may be driven by the expectation of negative future news. However, there is no reason to expect this effect to be larger for departures from High KHC firms than from Low KHC firms, as is predicted by the key human capital story. Furthermore, there is little evidence of this channel in the literature on CEO departures.

\section{Innovation and Key Human Capital}

In the previous section, we showed that firm value declines when key employees voluntarily leave their firms. In this section, we investigate one mechanism through which key employees create value: innovation. Although not all key employees are scientists or researchers, we showed earlier that many have advanced degrees and also that key human capital tends to be concentrated in innovative industries. With this motivation in mind, we test whether firms with key human capital are more innovative than those without.

We do so by estimating regressions with measures of innovation as the dependent variable and key human capital as an independent variable of interest. Specifically, we measure innovation using the natural logarithm of the number of patents filed during the calendar year and also by the logarithm of the number of citations those patents have received because patents differ greatly in their importance (Trajtenberg (1990)). We include industry and time fixed effects in all specifications, and robust standard errors are clustered at the firm level. As is common in the innovation literature, we exclude all financial and utility firms from this analysis.

The results of the analysis are displayed in Table 6. In column 1, we include only key human capital and fixed effects. The results are consistent with those of Panel B in Table 1. Firms with key human capital produce approximately $16 \%$ fewer patents than do their industry peers. However, in general, larger firms produce more patents, and firms with key human capital tend to be small. The model in column 2 of Table 6 controls for firm size. The $R^{2}$ of the regression jumps from $16 \%$ in column 1 to $35 \%$ in column 2 , indicating that firm size is an important determinant of innovation output. Importantly, the inclusion of firm size in the regression causes the sign on key human capital to flip to a significantly positive 0.06. This suggests that firms with key human capital produce $6 \%$ more patents than do similarly sized industry peers.

Of course, we have shown that firms with key human capital differ from those without along many dimensions other than just size. The model in column 3 of Table 6 includes additional controls for firm characteristics that have been shown to influence innovation, as well as characteristics that were shown earlier to be correlated with key human capital. The results show that firms with key human capital produce, on average, $9 \%$ more patents per year than similar firms within the same industry. From an economic standpoint, the impact of key human capital on innovation is moderate compared with that of other firm characteristics.

For instance, 1-standard-deviation increases in size, age, and growth opportunities are associated with $57 \%, 16 \%$, and $18 \%$ increases in innovation, respectively. Consistent with Kortum and Lerner (2000), VC backing is also important for innovation. Firms that were backed by VC during their IPOs produce $23 \%$ 
TABLE 6

Innovation and Key Human Capital

Panel A of Table 6 displays the coefficient estimates and their standard errors clustered at the firm level for linear regressions of two measures of innovation. In(NUMBER_OF_PATENTS) is the natural logarithm of the number of patents filed for by the firm in a given year. In(NUMBER_OF_CITATIONS) is the natural logarithm of the number of citations of the patents filed for by the firm in a given year. KEY_HUMAN_CAPITAL is an indicator variable that is equal to 1 if the firm discloses whether it carries key man life insurance, and 0 otherwise. INSURE_KEY_EMPLOYEE is a dummy variable that is equal to 1 if the firm discloses that it carries key man insurance, and 0 otherwise. KEY_EMPLOYEE_IS_DOCTOR is a dummy variable indicating that at least one of the firm's key employees has a medical degree or PhD, and MISSING_EDUCATION is a dummy variable that indicates that the key employee's educational background is missing. All explanatory variables are lagged by 1 year, unless noted otherwise, and definitions are included in Appendix C. In columns 1-5 and 7-11, the sample includes the panel of all nonfinancial and nonutility firms traded on the NYSE/NASDAQ/AMEX from 1998 to 2007. In columns 6 and 12, the sample includes only firms that disclose that they carry key man life insurance on at least one key employee; thus, the analysis is conducted within the set of insuring firms. Panel B includes additional governance- and CEO-related explanatory variables. Industry fixed effects use the Fama-French (1997) 48 industries. ${ }^{*},{ }^{\star *}$, and ${ }^{* * *}$ indicate significance at the $10 \%, 5 \%$, and $1 \%$ levels, respectively.

Panel A. Full Sample

Dependent Variable: In(NUMBER_OF_PATENTS)

KEY_HUMAN_CAPITAL

INSURE_KEY_EMPLOYEE

KEY_EMPLOYEE_IS_DOCTOR

MISSING_EDUCATION

$\ln ($ REAL_ASSETS)

FIRM_AGE

Q

TANGIBILITY

$\begin{array}{cc}\frac{1}{-0.16^{\star \star \star}} & \frac{2}{0.06^{\star \star}} \\ (0.03) & (0.03)\end{array}$

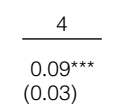

\begin{tabular}{c}
5 \\
\hline $0.08^{* *}$ \\
$(0.04)$ \\
0.02
\end{tabular}

0.02

$(0.04)$
$0.29^{* * *}$

$(0.01)$

Dependent Variable: In(NUMBER_OF_CITATIONS)

6

\begin{tabular}{|c|c|}
\hline 7 & 8 \\
\hline $\begin{array}{l}-0.20^{\star \star \star} \\
(0.05)\end{array}$ & $\begin{array}{l}0.10^{* *} \\
(0.04)\end{array}$ \\
\hline
\end{tabular}

$\frac{9}{0.12^{\star \star \star}}$

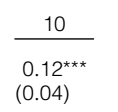

$0.27^{\star *}$

$(0.13)$

$-0.01$

(0.06)

\begin{tabular}{|c|c|c|c|}
\hline $\begin{array}{c}0.28^{\star \star \star} \\
(0.01)\end{array}$ & $\begin{array}{l}0.29^{\star \star \star} \\
(0.01)\end{array}$ & $\begin{array}{l}0.28^{* * *} \\
(0.01)\end{array}$ & 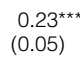 \\
\hline $\begin{array}{l}0.01^{\star \star \star} \\
(0.00)\end{array}$ & $\begin{array}{l}0.01^{\star \star \star} \\
(0.00)\end{array}$ & $\begin{array}{l}0.01^{\star \star *} \\
(0.00)\end{array}$ & $\begin{array}{c}0.01 \\
(0.01)\end{array}$ \\
\hline $\begin{array}{l}0.09^{\star \star *} \\
(0.01)\end{array}$ & $\begin{array}{l}0.08^{\star \star \star} \\
(0.01)\end{array}$ & $\begin{array}{l}0.09^{* * *} \\
(0.01)\end{array}$ & 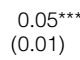 \\
\hline $\begin{array}{l}0.10^{\star \star} \\
(0.04)\end{array}$ & $\begin{array}{l}0.10^{\star \star \star} \\
(0.04)\end{array}$ & $\begin{array}{l}0.10^{* *} \\
(0.04)\end{array}$ & $\begin{array}{r}0.27^{*} \\
(0.16)\end{array}$ \\
\hline
\end{tabular}

$0.38^{\star \star \star}$
$(0.01)$

$\begin{array}{ll}0.38^{\star \star \star} & 0.39^{\star \star \star} \\ (0.01) & (0.01) \\ 0.01^{\star \star \star} & 0.01^{\star \star \star} \\ (0.00) & (0.00) \\ 0.15^{\star \star \star} & 0.14^{\star \star \star} \\ (0.01) & (0.01) \\ 0.15^{\star \star \star} & 0.16^{\star \star *} \\ (0.05) & (0.05)\end{array}$

11
$0.11^{* *}$
$(0.05)$
0.03
$(0.06)$

0.03

12

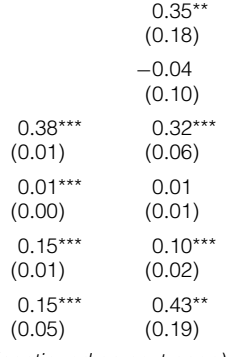

(continued on next page) 
TABLE 6 (continued)

Innovation and Key Human Capital

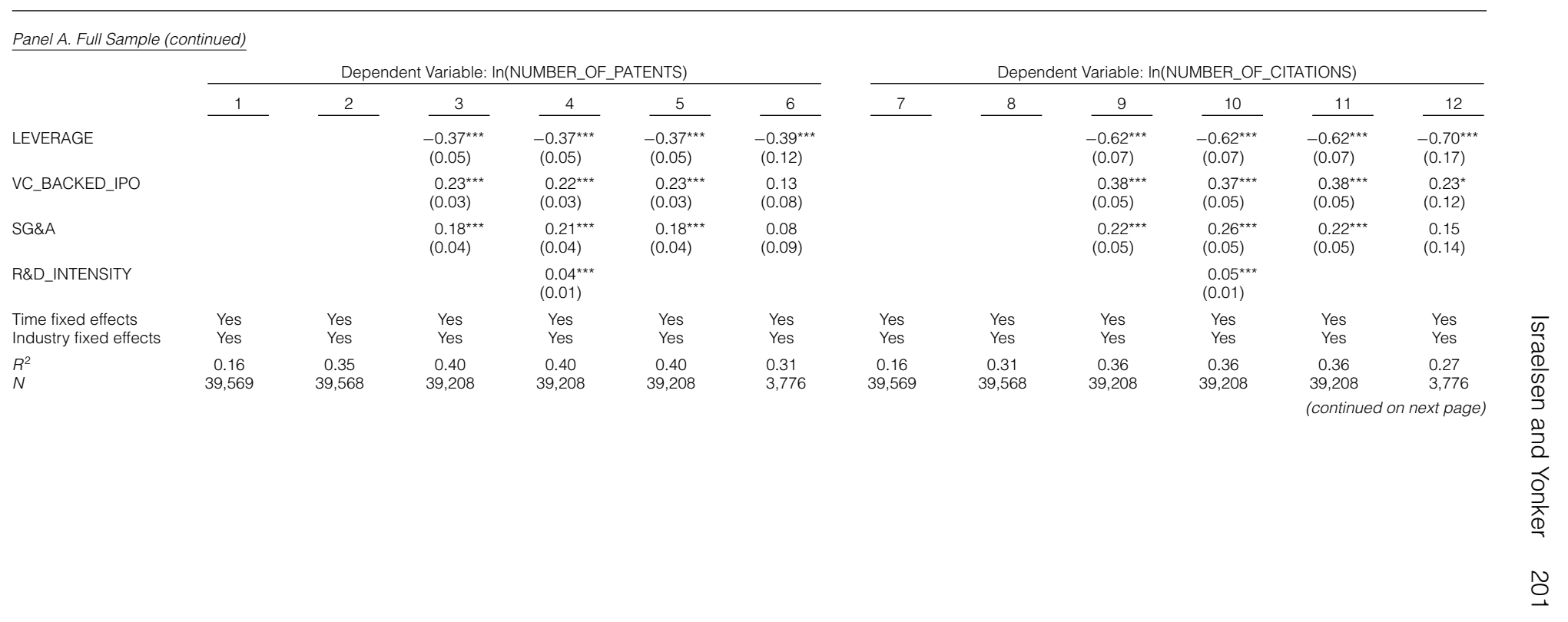


Innovation and Key Human Capital

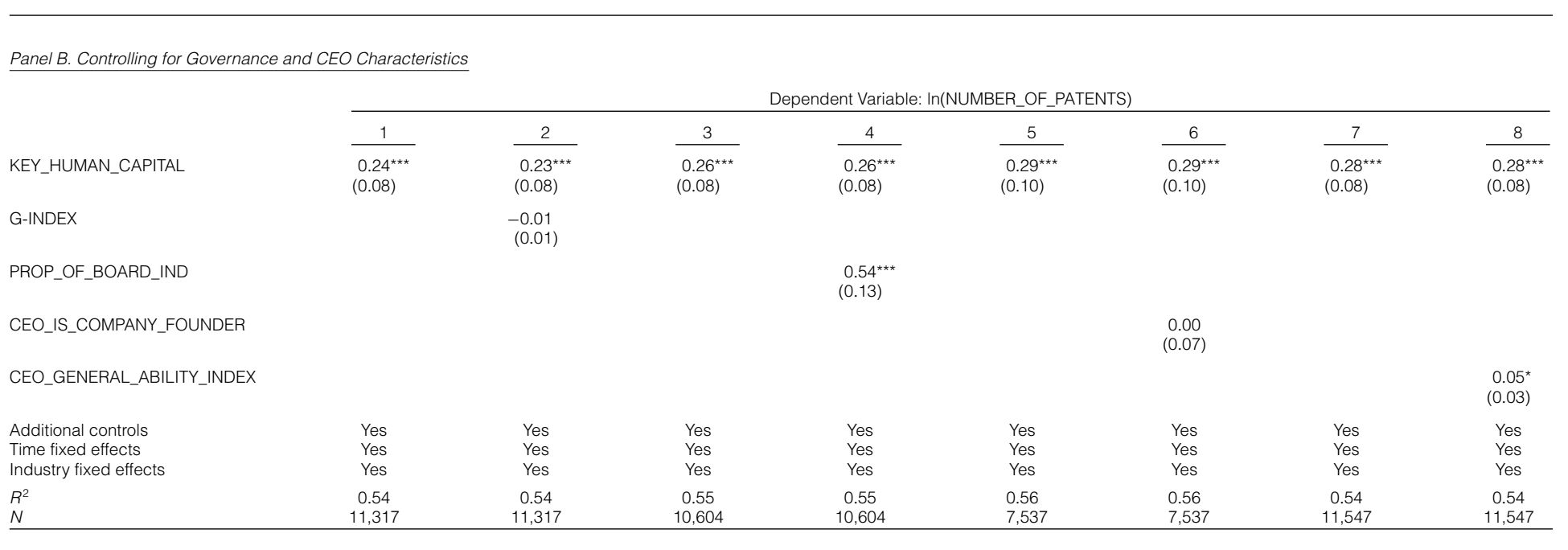


more patents. However, key human capital has a greater economic impact than other determinants of innovation, such as leverage, asset tangibility, and SG\&A.

The findings in columns 1-3 of Table 6 may be because firms with key human capital invest more in innovation, not that they are more effective innovators. In column 4 , the regression model includes R\&D intensity. This effectively controls for investment in innovation; thus, a positive coefficient estimate on key human capital in this regression indicates that firms with key human capital are more effective innovators. We find that this is indeed the case.

In column 5 of Table 6, we add INSURE_KEY_EMPLOYEE to the regression model from column 3 to test whether firms that insure the lives of their key employees are better innovators than those that do not. We find no evidence of this. This helps to rule out the story that insuring key employees gives firms access to capital, which allows them to innovate more.

Finally, in column 6 of Table 6, we test whether firms with key employees with $\mathrm{MD}$ or $\mathrm{PhD}$ degrees produce more innovation than firms with key employees without these degrees. Because not all key employees are necessarily innovators, it is interesting to test whether the ones who are most likely to be instrumental in the innovation process drive the results. Consistent with this notion, the regression coefficient on KEY_EMPLOYEE_IS_DOCTOR suggests that firms whose key employees are doctors produce approximately $27 \%$ more patents than do firms whose key employees are not doctors.

In columns $7-12$ of Table 6 , we show that the results are very similar if the dependent variable is the natural logarithm of patent citations instead of patents. Patent data, however, have been shown to suffer from truncation bias (Hall et al. (2001)). We show in Table IA.2 in the Internet Appendix that our results are also robust to using truncation-adjusted citation measures. ${ }^{30}$ Finally, in Panel B of Table 6, we show that controlling for governance and CEO characteristics does not affect the coefficient estimates on key human capital. ${ }^{31}$

\section{Is There a Key Man Premium?}

In this section, we provide preliminary evidence on whether key human capital represents a systematic source of risk from the standpoint of an investor. The tests are conducted using monthly returns from 1998 to 2010. In total, there are 156 months of data, which is a substantially shorter time series than that used by most asset pricing studies and constrains our ability to estimate factor loadings. The tests are limited to this window because 1997 was the first year that SEC filings became electronically available for all firms. As described earlier, these filings are necessary for the identification of key man insurance disclosures.

We perform characteristic-based tests by forming two portfolios based on 1-year lagged KEY_HUMAN_CAPITAL. The portfolio exposed to key human capital risk is composed of stocks where KEY_HUMAN_CAPITAL $=1$, and the unexposed portfolio is made up of stocks where KEY_HUMAN_CAPITAL $=0$.

\footnotetext{
${ }^{30}$ This analysis uses a shortened sample period because only data through 2003 are utilized in the NBER patent database.

${ }^{31}$ The positive coefficient on the CEO GAI is consistent with the findings of Custódio, Ferreira, and Matos (2014).
} 
If investors require a premium for their exposure to key human capital risk, then the zero-cost portfolio that is long the exposed portfolio and short the unexposed portfolio should yield positive risk-adjusted returns.

Panel A of Table 7 displays the results of the test using the Fama-French (1993) 4-factor model (FF4), which includes the momentum factor of Carhart (1997), to price the portfolios and the characteristic-adjusted returns from Daniel, Grinblatt, Titman, and Wermers (DGTW) (1997) and Wermers (2004). ${ }^{32}$ The exposed portfolio is composed of approximately $20 \%$ of all stocks each month on average, whereas the unexposed portfolio contains the remaining $80 \%$. The difference in the risk-adjusted returns between the two portfolios is close to 0 (between -2 bps and 2 bps) and not statistically different from 0 .

This finding suggests that investors do not require a premium to hold stocks exposed to key human capital risk. However, it may be that differences in firm characteristics other than key human capital exposure make it difficult to detect a key human capital premium. Many firms exposed to key human capital risk are small, growth firms, which tend to have anomalously low returns (Fama and French (1993)). Additionally, the firm-specific part of key human capital is the portion that should matter to diversified investors. These portfolios ignore any heterogeneity in that dimension. A better way to conduct the asset pricing tests is to sort stocks based on this firm-specific component within the set of disclosing firms.

Thus, we employ another technique. Recall that our measure of key human capital intensity (KHC) is a measure of the firm-specific component of key human capital. Thus, it allows us to test whether firms with greater exposure to key human capital risk are riskier within the set of exposed firms. For each year from 1997-2009, we create tercile portfolios by sorting on key human capital intensity. These portfolios are held for the following calendar year, and the equal-weighted return of each tercile is calculated. On average, there are 98 stocks in each tercile portfolio and 196 in the long-short portfolio.

Panel B of Table 7 shows the returns to the KHC-sorted portfolios and the average KHC levels. In the first few columns, we see that the average key human capital intensities of the low, medium, and high portfolios are 1\%, 4\%, and $25 \%$, respectively, for a spread of $24 \%$. Although the firms with low key human capital intensity carry key man life insurance, the amount of coverage represents only a very small fraction of their total assets. Excess returns increase monotonically from the lowest to the highest tercile. The average raw monthly excess return on the long-short portfolio is $101 \mathrm{bps}$.

The stocks used to form these portfolios tend to be those of smaller, growth firms. To test whether the returns are simply compensation for risk unrelated to key human capital, we again calculate DGTW- and FF4-adjusted returns. The right-hand side of Panel $\mathrm{B}$ in Table 7 provides alphas, factor loadings, and $t$ statistics for the KHC-sorted tercile and long-short portfolios. Abnormal returns also increase monotonically from the Low KHC portfolio to the High KHC portfolio using either risk adjustment. The portfolio that is long High KHC stocks and

\footnotetext{
${ }^{32}$ The DGTW benchmarks are available via http://alex2.umd.edu/wermers/ftpsite/Dgtw/coverpag e.htm.
} 
TABLE 7

\section{Returns to Key Human Capital}

Table 7 displays the coefficient estimates and $t$-statistics for asset pricing tests of equal-weighted stock portfolios formed based on key human capital (Panel A) and on key human capital intensity (KHC) (Panel B). The KEY_HUMAN_CAPITAL dummy is an indicator variable that is equal to 1 if the firm discloses whether it insures key employees, and 0 otherwise. KEY_HUMAN_CAPITAL_INTENSITY is the ratio of the firm's aggregate key man life insurance policy amounts to total firm assets. The portfolios in Panel A are created from the common stock of all nonfinancial firms traded on the NYSE, AMEX, or NASDAQ with returns available in CRSP. The portfolios in Panel B are composed of the subset of those used in Panel A that disclose key man insurance policy amounts. Table 7 shows results using the FF4 (Fama and French (1993)), which includes the momentum factor of Carhart (1997) and the characteristic-adjusted returns from Daniel et al. (1997) and Wermers (2004) (DGTW). The models are estimated using 156 monthly portfolio returns from 1998 to 2010

Panel A. Portfolios Based on Key Human Capital

\begin{tabular}{|c|c|c|}
\hline Portfolio & $\begin{array}{l}\text { Excess } \\
\text { Returns }\end{array}$ & $\begin{array}{l}\text { Avg. No. of } \\
\text { Stocks }\end{array}$ \\
\hline $\begin{array}{l}\text { KEY_HUMAN_CAPITAL }=0 \\
\text { KEY_HUMAN CAPITAL }=1\end{array}$ & $\begin{array}{l}1.11 \\
1.11\end{array}$ & $\begin{array}{r}3,108 \\
760\end{array}$ \\
\hline $1-0$ & 0.00 & \\
\hline
\end{tabular}

\begin{tabular}{|c|c|c|c|c|c|}
\hline \multicolumn{6}{|c|}{ Estimates } \\
\hline$\alpha_{D G T W}$ & $\alpha_{F F 4}$ & $\beta_{M K T}$ & $\beta_{S M B}$ & $\beta_{\text {HML }}$ & $\beta_{\cup M D}$ \\
\hline 0.36 & 0.83 & 1.00 & 0.77 & 0.05 & -0.24 \\
\hline 0.34 & 0.85 & 1.10 & 1.02 & -0.30 & -0.34 \\
\hline-0.02 & 0.02 & 0.10 & 0.24 & -0.35 & -0.10 \\
\hline
\end{tabular}

\begin{tabular}{|c|c|c|c|c|c|}
\hline \multicolumn{6}{|c|}{$t$-Statistics } \\
\hline$\alpha_{D G T W}$ & $\alpha_{F F 3}$ & $\beta_{\text {MKT }}$ & $\beta_{S M B}$ & $\beta_{H M L}$ & $\beta_{U M D}$ \\
\hline 2.59 & 5.39 & 29.18 & 17.84 & 1.14 & -9.07 \\
\hline 1.28 & 3.31 & 19.39 & 14.17 & -4.06 & -7.72 \\
\hline-0.15 & 0.12 & 3.45 & 6.61 & -9.26 & -4.38 \\
\hline
\end{tabular}

Panel B. Portfolios Sorted on Key Human Capital Intensity (KHC)

\begin{tabular}{|c|c|c|c|c|c|c|c|c|c|c|c|c|c|c|c|}
\hline \multirow[b]{2}{*}{ Portfolio } & \multirow{2}{*}{$\begin{array}{l}\text { Avg. } \\
\text { KHC }\end{array}$} & \multirow{2}{*}{$\begin{array}{l}\text { Excess } \\
\text { Returns } \\
\end{array}$} & \multirow{2}{*}{$\begin{array}{l}\text { Avg. No. of } \\
\text { Stocks }\end{array}$} & \multicolumn{6}{|c|}{ Estimates } & \multicolumn{6}{|c|}{$t$-Statistics } \\
\hline & & & & $\alpha_{D G T W}$ & $\alpha_{F F 4}$ & $\beta_{M K T}$ & $\beta_{S M B}$ & $\beta_{H M L}$ & $\beta_{U M D}$ & $\alpha_{D G T W}$ & $\alpha_{F F 4}$ & $\beta_{M K T}$ & $\beta_{S M B}$ & $\beta_{H M L}$ & $\beta_{U M D}$ \\
\hline $\begin{array}{l}\text { Low } \\
\text { Medium } \\
\text { High }\end{array}$ & $\begin{array}{l}0.01 \\
0.04 \\
0.25\end{array}$ & $\begin{array}{l}0.58 \\
0.95 \\
1.60\end{array}$ & $\begin{array}{l}98 \\
98 \\
98\end{array}$ & $\begin{array}{r}-0.17 \\
0.03 \\
0.67\end{array}$ & $\begin{array}{l}0.29 \\
0.69 \\
1.49\end{array}$ & $\begin{array}{l}1.12 \\
1.02 \\
0.86\end{array}$ & $\begin{array}{l}0.91 \\
1.03 \\
1.18\end{array}$ & $\begin{array}{l}-0.09 \\
-0.23 \\
-0.61\end{array}$ & $\begin{array}{l}-0.33 \\
-0.35 \\
-0.49\end{array}$ & $\begin{array}{r}-0.68 \\
0.10 \\
1.49\end{array}$ & $\begin{array}{l}1.35 \\
1.94 \\
2.88\end{array}$ & $\begin{array}{r}23.46 \\
12.85 \\
7.50\end{array}$ & $\begin{array}{r}15.00 \\
10.20 \\
8.11\end{array}$ & $\begin{array}{l}-1.44 \\
-2.28 \\
-4.12\end{array}$ & $\begin{array}{l}-8.88 \\
-5.75 \\
-5.52\end{array}$ \\
\hline High - Low & 0.24 & 1.01 & & 0.84 & 1.20 & -0.26 & 0.27 & -0.52 & -0.16 & 2.12 & 2.88 & -2.85 & 2.30 & -4.37 & -2.26 \\
\hline
\end{tabular}


short Low KHC stocks generates DGTW-characteristic-adjusted returns of 84 bps per month and FF4-adjusted returns of 120 bps per month. These statistically significant abnormal long-short portfolio returns suggest that High KHC stocks are systematically more risky than Low KHC stocks. ${ }^{33}$

Recall that key human capital is riskiest when concentrated and that we expect this risk to be more important to small rather than large firms. For this reason, we test whether the premium is larger in the portfolios of small firms compared with large firms. In Table 8, we construct portfolios that are formed by sequentially sorting stocks based on size and then on key human capital intensity. We then test for differences between the High and Low KHC portfolios within the sets of small and large firms. The results show a statistically significant positive key human capital intensity premium of 92-100 bps within the set of small firms. However, this premium is only between $15 \mathrm{bps}$ and $23 \mathrm{bps}$ for the set of large firms and is not statistically different from 0 . This suggests that investors realize that key human capital is riskiest in small firms and that only in these firms that they require a premium to hold firms exposed to key human capital risk.

Although our sample period is admittedly short, we provide preliminary evidence that investors require compensation for holding firms with key human capital risk. This is the strongest in small firms. Whether this risk is priced in the full cross section of returns is left for further research.

\section{Robustness and Additional Analysis}

In this section, we discuss a number of the unreported robustness checks.

\section{A. Financial Constraints}

When collecting data on disclosures, we found some evidence of firms holding key man life insurance to satisfy a covenant with a lender. This suggests that lenders recognize the risk of key human capital and also that our disclosing firms may be financially constrained. Additionally, we find that both leverage and Tobin's $Q$ are positively related to firms disclosing their key human capital risk. These are two variables that are used to predict financially constrained firms in the KZ index of Lamont, Polk, and Saá-Requejo (2001), which is based on the estimates by Kaplan and Zingales (1997). Following Lamont et al. (2001), we compute the $\mathrm{KZ}$ index for each firm-year observation. Inconsistent with disclosing firms being financially constrained, the coefficient estimate on the KZ index is not statistically different from 0 when included as a determinant of KEY_HUMAN_CAPITAL.

\section{B. Alternative Measures of Exposure to Key Human Capital}

As an alternative to using key man insurance disclosures, we take the more general approach of identifying firms that disclose that they have "key" employees in their 10-K filings. Eisfeldt and Papanikolaou (2013) collect this measure for a random sample of 100 firms (10 firms each year for 10 years) to validate their organizational capital measure and find that firms with high organizational

\footnotetext{
${ }^{33}$ Results are virtually unchanged if the liquidity factor of Pastor and Stambaugh (2003) is added to the model.
} 


\section{TABLE 8}

\section{Returns to Key Human Capital: Double-Sorted Portfolios}

Table 8 displays the coefficient estimates and $t$-statistics for asset pricing tests of equal-weighted stock portfolios formed based on key human capital intensity and firm size. Portfolios are formed by sequentially sorting stocks based on size and then key human capital intensity. Key human capital intensity (KHC) is the ratio of the firm's aggregate key man life insurance policy amounts to total firm assets. Portfolios are created from the common stock of all nonfinancial firms traded on the NYSE, AMEX, or NASDAQ with returns available in CRSP that disclose key man insurance policy amounts. Table 8 shows results using the FF4 (Fama and French (1993)), which includes the momentum factor of Carhart (1997) and the characteristic-adjusted returns from Daniel et al. (DGTW) (1997) and Wermers (2004). The models are estimated using 156 monthly portfolio returns from 1998 to 2010.

\begin{tabular}{|c|c|c|c|c|c|c|c|c|c|c|c|c|c|c|c|}
\hline \multirow[b]{2}{*}{ Portfolio } & \multirow{2}{*}{$\begin{array}{l}\text { Avg. } \\
\mathrm{KHC} \\
\end{array}$} & \multirow{2}{*}{$\begin{array}{l}\text { Excess } \\
\text { Returns } \\
\end{array}$} & \multirow{2}{*}{$\begin{array}{l}\text { Avg. No. of } \\
\text { Stocks } \\
\end{array}$} & \multicolumn{6}{|c|}{ Estimates } & \multicolumn{6}{|c|}{$t$-Statistics } \\
\hline & & & & $\alpha_{\mathrm{DGTW}}$ & $\alpha_{\mathrm{FF} 4}$ & $\beta_{\mathrm{MKT}}$ & $\beta_{\mathrm{SMB}}$ & $\beta_{\mathrm{HML}}$ & $\beta_{\mathrm{UMD}}$ & $\alpha_{\mathrm{DGTW}}$ & $\alpha_{\mathrm{FF} 4}$ & $\beta_{\mathrm{MKT}}$ & $\beta_{\mathrm{SMB}}$ & $\beta_{\mathrm{HML}}$ & $\beta_{\cup M D}$ \\
\hline Small: Low KHC & 0.02 & 1.11 & 49 & 0.10 & 1.01 & 0.84 & 0.92 & -0.27 & -0.46 & 0.23 & 2.20 & 8.25 & 7.09 & -2.05 & -5.81 \\
\hline Small: Medium KHC & 0.08 & 1.90 & 49 & 0.65 & 1.82 & 0.80 & 1.12 & -0.43 & -0.56 & 1.35 & 2.92 & 5.80 & 6.40 & -2.40 & -5.29 \\
\hline Small: High KHC & 0.35 & 1.94 & 49 & 1.10 & 1.93 & 0.67 & 1.24 & -0.68 & -0.61 & 1.82 & 2.95 & 4.64 & 6.71 & -3.60 & -5.47 \\
\hline Small: High - Low KHC & 0.32 & 0.82 & & 1.00 & 0.92 & -0.16 & 0.33 & -0.41 & -0.16 & 2.04 & 2.00 & -1.60 & 2.50 & -3.08 & -2.00 \\
\hline Large: Low KHC & 0.00 & 0.23 & 49 & -0.32 & -0.11 & 1.25 & 0.94 & -0.01 & -0.37 & -1.01 & -0.47 & 23.16 & 13.64 & -0.13 & -8.96 \\
\hline Large: Medium KHC & 0.02 & 0.56 & 49 & -0.29 & 0.19 & 1.13 & 0.96 & -0.10 & -0.18 & -1.14 & 0.78 & 21.10 & 14.18 & -1.40 & -4.41 \\
\hline Large: High KHC & 0.12 & 0.51 & 49 & -0.18 & 0.11 & 1.31 & 1.07 & -0.39 & -0.14 & -0.50 & 0.32 & 16.88 & 10.79 & -3.86 & -2.41 \\
\hline Large: High - Low KHC & 0.12 & 0.28 & & 0.15 & 0.23 & 0.06 & 0.13 & -0.38 & 0.23 & 0.40 & 0.62 & 0.77 & 1.27 & -3.62 & 3.67 \\
\hline Equal-weighted Avg.: High - Low KHC & 0.22 & 0.55 & & 0.57 & 0.57 & -0.05 & 0.23 & -0.39 & 0.04 & 1.76 & 1.81 & -0.72 & 2.55 & -4.32 & 0.65 \\
\hline
\end{tabular}


capital are more likely to make these key employee disclosures. We construct this measure for all firms in our sample (roughly 4,000 firms per year for 13 years). ${ }^{34}$

We find that firms making these key employee disclosures have characteristics similar to those that make key man insurance disclosures; however, they tend to be much larger and older, and they have lower investment in R\&D and SG\&A. In addition, these firms tend to be less risky, and the disclosure of key employees over time shows a dramatic upward trend. Many firms making these key employee disclosures seem to be motivated by reducing corporate liability in the event that they are hurt by the loss of an employee. We conclude that key man insurance disclosures are much more informative because firms that are truly exposed will likely make more detailed disclosures showing that they considered ways of mitigating key employee risk.

\section{Alternative Measures of Propensity to Make Disclosures}

In addition to using the number of $8-\mathrm{K}$ filings in the previous year as a proxy for the propensity to make nonmandatory disclosures, we also construct another measure: the natural $\log$ of the number of words in the $10-\mathrm{K}$ filing. Similar to $\ln$ (NUMBER_OF_8K_FILINGS), this measure is also positively related to KEY_HUMAN_CAPITAL, and including it in the regressions of risk on KEY_HUMAN_CAPITAL, as in Table 5, has no effect on our estimates of the relationship between KEY_HUMAN_CAPITAL and firm risk.

\section{Conclusion}

This paper identifies and measures an important type of human capital referred to as key human capital, which is the human capital associated with a firm's key employees. Key employees differ from other employees for two reasons: i) They possess a large fraction of their firm's human capital, and ii) they are difficult, if not impossible, to replace following departure. Thus, firms with key human capital should be more risky.

One of the biggest struggles in the literature on human capital, or intangible assets more generally, is measurement. We take a novel, direct approach in identifying firms exposed to key human capital risk by examining firms' disclosures of corporate-owned life insurance policies. Firms exposed to key human capital risk tend to be younger, smaller, growth firms in what are generally considered human-capital-intensive industries. Their key employees are 5 times more likely to have a $\mathrm{PhD}$ or an MD degree than the typical executive.

Our unique measure allows us to show that firms exposed to key human capital risk have total and idiosyncratic stock return volatilities 5\%-20\% higher than firms with no such exposure. Moreover, we examine stock returns around announcements of the departure of key employees and find that firm value declines by $4 \%$ following the turnover, on average. This latter result is contrary to the puzzling results in the literature on wealth effects around executive turnover, which typically show no or even positive firm value effects when executives leave their firms. This suggests that the executives we identify as "key" are extremely

\footnotetext{
${ }^{34} \mathrm{~A}$ description of the procedure for identifying these firms is found in Appendix D.
} 
important to their firms. We show one way in which these key employees are valuable: through innovation.

Finally, we provide evidence that key human capital risk is important to diversified investors as well. We provide preliminary evidence that investors require a premium for exposure to firms with key human capital risk, particularly in small firms.

\section{Appendix A. Examples of "Key Man" Insurance Disclosures}

\section{THE LOSS OF EITHER THE CEO OR THE COO COULD ADVERSELY AFFECT OPERATIONS}

Our operations are dependent upon our Chief Executive Officer, Aubrey K. McClendon, and our Chief Operating Officer, Tom L. Ward. The unexpected loss of the services of either of these executive officers could have a detrimental effect on our operations. We maintain \$20 million key man life insurance policies on the life of each of Messrs. McClendon and Ward.

-Chesapeake Energy Corp., 10-K Filing (Mar. 30, 2000)

\section{DEPENDENCE ON KEY PERSONNEL AND ABILITY TO ATTRACT AND RETAIN PROFESSIONAL STAFF}

The Company is dependent upon the efforts and abilities of its senior management, its research and development staff and a number of other key management, sales, services, support and technical personnel. The success of the Company will depend to a large extent upon its ability to retain and continue to attract qualified technical and other employees. Competition for qualified personnel in the software industry is intense, and the loss of key employees could have a material adverse effect on the Company's business, financial condition and results of operations, particularly if key personnel are subsequently employed by a competitor. The Company carries key man life insurance in the amount of \$10 million with respect to its President and Chief Executive Officer, Joseph B. Costello.

—Cadence Design Systems, Inc., S-3 Filing (Jan. 28, 1997)

\section{DEPENDENCE UPON KEY MEMBERS OF MANAGEMENT}

The success of the Company is largely dependent on the efforts of Lawrence Butler, Chairman and Chief Executive Officer and Robert Streiter, President and Chief Operating Officer of the Company, respectively. The loss of their services could have a material adverse effect on the Company's business and prospects. The Company entered into employment agreements with Lawrence Butler and with Robert Streiter. We have a key man life insurance policy on the life of Robert Streiter for $\$ 10,000,000$, which has been assigned to secure our indebtedness described above.

—Alpha Technologies Group, Inc., S-8 Filing (May 25, 2001)

\section{DEPENDENCE ON KEY PERSONNEL}

The Company's continuing and future success depends in large part on the continued services of Mr. Steve Bostic, its Chairman and Chief Executive Officer, as well as certain of its other officers and key personnel. The loss of the services of Mr. Bostic, certain of the Company's officers or other key personnel could have a material adverse effect on the Company. The Company currently maintains key man life insurance policies on the life of Mr. Bostic in the aggregate 
amount of $\$ 27$ million, which policies have been pledged to secure certain indebtedness incurred by the Company. The Company and Mr. Bostic have not entered into an employment agreement. The Company's continuing and future success will also depend on its ability to attract and retain highly-skilled personnel, including its faculty. There can be no assurance that the Company will be successful in these recruitment and training efforts, and the failure to hire and train the intended complement of faculty members may have a material adverse effect on the Company's operations.

—Edutrek International, Inc., S-1 Filing (June 20, 1997)

\section{DEPENDENCE ON MANAGEMENT}

We are dependent upon the efforts of our executive officers and other key personnel and on our ability to continue to attract and retain qualified personnel in the future. The loss of certain of our executive officers and key personnel or our inability to attract and retain qualified personnel in the future could have a material adverse effect on our business and results of operations. We currently maintain key man insurance on the lives of certain key personnel including insurance on Thomas Kinkade in the amount of \$44 million.

—Media Arts Group, Inc., 10-K405 Filing (June 29, 2001)

\section{DEPENDENCE UPON KEY PERSONNEL}

The Company's future performance also depends in significant part upon the continued service of its key technical and senior management personnel, many of whom have been with the Company for a significant period of time. The Company does not maintain key man life insurance on any of its employees. Because the Company has a relatively small number of employees when compared to other leading companies in the same industry, its dependence on maintaining its relationship with key employees is particularly significant. The Company is also dependent on its ability to attract and retain high quality personnel, particularly in the areas of sales and applications development.

The industry is characterized by a high level of employee mobility and aggressive recruiting of skilled personnel. There can be no assurance that the Company's current employees will continue to work for the Company.

Loss of services of key employees could have a material adverse effect on the Company's business, results of operations and financial condition. Furthermore, the Company may need to grant additional stock options to key employees and provide other forms of incentive compensation to attract and retain such key personnel.

—Quality Systems, Inc., 10-K Filing (July 1, 2002)

\section{MATERIAL DEPENDENCE UPON KEY PERSONNEL}

The Company has been, and will continue to be, materially dependent upon the technical expertise of its engineering and management personnel. The loss of a significant number of such personnel would have a materially adverse effect upon the Company's business and future prospects. The Company does not maintain key-man life insurance.

-Imatron, Inc., 10-K Filing (Mar. 31, 1999) 


\section{Appendix B. List of 50 Key Human Capital Firms}

Table B1 in Appendix B displays data on key employee disclosures for a sample of 50 firms making such disclosures (35 insuring and 15 not insuring). For each firm, we include the CIK, the filing type, the filing date, whether the firm holds insurance, and the named key employees and policy amounts if firms hold insurance.

\section{TABLE B1}

\section{List of 50 Key Human Capital Firms}

Table B1 displays data on key employee disclosures for a sample of 50 firms making such disclosures (35 insuring and 15 not insuring). For each firm, we include the CIK, the filing type, the filing date, whether the firm holds insurance, and the named key employees and policy amounts if firms hold insurance.

\begin{tabular}{|c|c|c|c|c|c|c|}
\hline $\mathrm{CIK}$ & Company Name & $\begin{array}{l}\text { Filing } \\
\text { Type }\end{array}$ & $\begin{array}{l}\text { Filing } \\
\text { Date }\end{array}$ & $\begin{array}{c}\text { Insure } \\
\text { Key Employee }\end{array}$ & $\begin{array}{c}\text { Key } \\
\text { Employee }\end{array}$ & $\begin{array}{c}\text { Policy Amount } \\
\text { (\$thousands) }\end{array}$ \\
\hline 903129 & Amerigon Inc. & S-2/A & 01/15/1997 & Yes & $\begin{array}{l}\text { Mr. Joshua E. Newman } \\
\text { Dr. Lon E. Bell }\end{array}$ & $\begin{array}{l}1,000 \\
2,000\end{array}$ \\
\hline 849433 & Ansoft Corp. & $10-Q$ & $03 / 14 / 2000$ & Yes & Dr. Zoltan J. Cendes & 5,000 \\
\hline 798399 & Applied Innovation Inc. & $10-\bar{K}$ & $03 / 27 / 2001$ & Yes & Gerard B. Moersdorf, Jr. & 10,000 \\
\hline 845289 & Benton Oil Gas Co. & 424B2 & 01/20/1998 & Yes & A. E. Benton & 5,000 \\
\hline 876343 & Biotime Inc. & $10-\mathrm{K}$ & 03/31/2003 & Yes & Dr. Paul Segall & 1,000 \\
\hline 830656 & Boston Biomedica Inc. & S-3 & $01 / 11 / 2000$ & Yes & Richard T. Schumacher & 10,000 \\
\hline 813672 & Cadence Design Systems Inc. & S-3 & 01/28/1997 & Yes & Joseph B. Costello & 10,000 \\
\hline 1063085 & Catapult Communications Corp. & $10-\mathrm{K}$ & $01 / 07 / 2000$ & Yes & Dr. Richard A. Karp & 2,000 \\
\hline 1030653 & Curagen Corp. & $10-\mathrm{K}$ & 03/14/2005 & Yes & Dr. Jonathan M. Rothberg & 2,000 \\
\hline 768411 & Cyberoptics Corp. & $10-K 405$ & 03/27/1998 & Yes & Dr. Steven K. Case & 5,000 \\
\hline 872912 & Delcath Systems Inc. & SB-2 & $06 / 16 / 2000$ & Yes & $\begin{array}{l}\text { Dr. Samuel Herschkowitz } \\
\text { M. S. Koly }\end{array}$ & $\begin{array}{l}2,000 \\
2,000\end{array}$ \\
\hline 750901 & Fischer Imaging Corp. & $10-K$ & 03/31/1998 & Yes & Morgan W. Nields & 5,000 \\
\hline 315272 & Harcor Energy Inc. & S-3 & 04/30/1997 & Yes & Mark G. Harrington & 10,000 \\
\hline 946644 & Hemispherx Biopharma Inc. & $10-K$ & $03 / 17 / 2008$ & Yes & Dr. William A. Carter & 2,000 \\
\hline 1052958 & Horizon Medical Products Inc. & $10-K$ & $04 / 16 / 2002$ & Yes & $\begin{array}{l}\text { William E. Peterson, Jr. } \\
\text { Marshall B. Hunt }\end{array}$ & $\begin{array}{l}1,000 \\
1,000\end{array}$ \\
\hline 722830 & Immunomedics Inc. & $10-\mathrm{K}$ & 09/26/2003 & Yes & Dr. David Goldenberg & 4,000 \\
\hline 1068874 & Implant Sciences Corp. & S-3 & $04 / 14 / 2005$ & Yes & $\begin{array}{l}\text { Dr. Anthony J. Armini } \\
\text { Dr. Stephen N. Bunker }\end{array}$ & $\begin{array}{r}1,000 \\
500\end{array}$ \\
\hline 1088724 & Informax Inc. & S-1 & $07 / 11 / 2000$ & Yes & $\begin{array}{l}\text { Dr. Alex Titomirov } \\
\text { Dr. Vadim Babenko }\end{array}$ & $\begin{array}{l}2,000 \\
2,000\end{array}$ \\
\hline 822663 & Inter Parfums Inc. & $10-\mathrm{K}$ & 03/10/2010 & Yes & Philippe Benacin & 22,000 \\
\hline 1110206 & Kosan Biosciences Inc. & $10-\mathrm{K}$ & 03/28/2003 & Yes & $\begin{array}{l}\text { Dr. Daniel V. Santi } \\
\text { Dr. Chaitan S. Khosla }\end{array}$ & $\begin{array}{l}1,000 \\
1,000\end{array}$ \\
\hline 913241 & Madden Steven Ltd. & S-3 & 02/17/1998 & Yes & Steven Madden & 10,000 \\
\hline 924645 & Media Arts Group Inc. & $10-\mathrm{K}$ & 06/29/1999 & Yes & Thomas Kinkade & 60,000 \\
\hline 1090507 & Medis Technologies Ltd. & $10-K$ & $03 / 14 / 2006$ & Yes & Gennadi Finkelshtain & 3,000 \\
\hline 702131 & Mgi Pharma Inc. & S-3/A & $01 / 02 / 2001$ & Yes & Charles N. Blitzer & 5,000 \\
\hline 855683 & Milestone Scientific Inc./NJ & S-3 & 04/30/1997 & Yes & $\begin{array}{l}\text { Leonard A. Osser } \\
\text { Gregory Volok }\end{array}$ & $\begin{array}{l}3,000 \\
3,000\end{array}$ \\
\hline 808013 & North American Technologies Group Inc. & $10 \mathrm{KSB}$ & 03/29/2000 & Yes & Dr. Henry W. Sullivan & 3,000 \\
\hline 790023 & Pacific Aerospace Electronics Inc. & $10-\mathrm{K}$ & 08/28/1998 & Yes & Donald A. Wright & 8,000 \\
\hline 888455 & Petco Animal Supplies Inc. & $10-\mathrm{K}$ & 04/30/1999 & Yes & Brian K. Devine & 1,000 \\
\hline 790526 & Primedex Health Systems Inc. & $10-\mathrm{K}$ & 02/06/2004 & Yes & Dr. Howard Berger & 5,000 \\
\hline 835887 & Progenics Pharmaceuticals Inc. & $10-\mathrm{K}$ & 03/31/1998 & Yes & Dr. Paul J. Maddon & 2,500 \\
\hline 793971 & Sound Advice Inc. & S-1 & 05/08/2000 & Yes & Peter Beshouri & 5,000 \\
\hline 1108674 & Stratagene Corp. & $10-Q$ & 08/10/2006 & Yes & Dr. Joseph A. Sorge & 10,000 \\
\hline 919722 & Supergen Inc. & S-3 & $01 / 12 / 1999$ & Yes & Dr. Joseph Rubinfeld & 2,100 \\
\hline 1174922 & Wynn Resorts Ltd. & S- $1 / A$ & 10/21/2002 & Yes & Stephen A. Wynn & 30,000 \\
\hline 1096509 & Z Tel Technologies Inc. & $10-\mathrm{K}$ & 03/28/2000 & Yes & D. Gregory Smith & 5,000 \\
\hline 1071806 & Aquantive Inc. & $10-\mathrm{K}$ & 03/02/2006 & No & & \\
\hline 18937 & Ceradyne, Inc. & $10-K$ & $02 / 24 / 2009$ & No & & \\
\hline 1049480 & Doubleclick Inc. & $10-\mathrm{K}$ & 03/10/2004 & No & & \\
\hline 1297401 & Dreamworks Animation Skg, Inc. & $10-\mathrm{K}$ & 03/28/2005 & No & & \\
\hline 1041652 & lomed Inc. & S-1/A & 04/23/1998 & No & & \\
\hline 755806 & Neorx Corp. & $10-K$ & 03/25/1998 & No & & \\
\hline 1068885 & Netsilicon Inc. & $10-K 405$ & 05/01/2001 & No & & \\
\hline 1043873 & Novadel Pharma Inc. & $10-K$ & 03/26/2007 & No & & \\
\hline 1120914 & Pdf Solutions Inc. & S-1/A & 07/24/2001 & No & & \\
\hline 1002663 & Photon Dynamics Inc. & $10-K 405$ & $11 / 07 / 2000$ & No & & \\
\hline 806517 & Psychemedics Corp. & $10-\mathrm{K}$ & 03/24/2008 & No & & \\
\hline 709519 & Sun Microsystems, Inc. & $10-\mathrm{K}$ & 09/27/1999 & No & & \\
\hline 1014473 & Verisign Inc./CA & $10-\mathrm{K}$ & 03/19/2002 & No & & \\
\hline 1324570 & Volcom Inc. & S-1 & 04/29/2005 & No & & \\
\hline 1011006 & Yahoo Inc. & $10-K$ & 03/12/1998 & No & & \\
\hline
\end{tabular}




\section{Appendix C. Variable Definitions}

Appendix $\mathrm{C}$ provides definitions of the variables used in the study. All accounting variables are winsorized at the $1.00 \%$ level.

$\ln$ (TOTAL_REAL_ASSETS) Natural logarithm of total real assets in 2005 dollars. Source: Compustat.

FIRM_AGE Number of years since the company's IPO. Source: Compustat.

Q Market value of total assets to lagged book value of total assets. Source: Compustat/CRSP.

TANGIBILITY Net property, plant, and equipment to lagged book value of total assets. Source: Compustat.

R\&D_INTENSITY R\&D expenditures to lagged book value of total assets. Missing values are substituted with 0 . Source: Compustat.

LEVERAGE Total debt in long-term liabilities plus total debt in current liabilities divided by lagged book value of total assets. Source: Compustat.

VC_BACKED_IPO An indicator variable that is 1 if the IPO was backed by venture capital, and 0 otherwise. Source: SDC Platinum.

$\ln$ (NUMBER_OF_8K_FILINGS) The natural logarithm of the number of nonmandatory 8 -K filings made by the firm in the previous year. Source: SEC filings.

SG\&A Sales, general, and administrative expense to lagged book value of total assets. Source: Compustat.

G_INDEX The governance index of Gompers et al. (2003). Source: RiskMetrics.

PROP_BOARD_IND The proportion of independent directors on the board. Source: RiskMetrics.

CEO_GENERAL_ABILITY_INDEX A measure of the degree to which the manager's skills are general versus firm specific from Custódio et al. (2013). Source: Available from the authors.

CEO_IS_COMPANY_FOUNDER An indicator variable that is equal to 1 if the current CEO founded the company, and 0 otherwise. Source: Fahlenbrach (2009).

STOCK_VOLATILITY Standard deviation of daily stock market returns during the calendar year. Source: CRSP.

STOCK_IDIOSYNCRATIC_VOLATILITY Standard deviation of the residual from regressing daily stock market returns on the Fama-French (1993) 3 factors using data during the calendar year. Source: CRSP/WRDS.

$\ln$ (NUMBER_OF_PATENTS) Natural logarithm of the number of patents filed during the year (Kogan et al. (2012)). Source: Noah Stoffman's Web site (https://kelley.iu.edu/ nstoffma/) and https://iu.app.box.com/v/patents.

$\ln$ (NUMBER_OF_CITATIONS) Natural logarithm of the number of citations of patents filed during the year (Kogan et al. (2012)). Source: Noah Stoffman's Web site (https: //kelley.iu.edu/nstoffma/).

KEY_HUMAN_CAPITAL An indicator variable that is equal to 1 if the firm discloses whether it holds key man life insurance on any of its employees, and 0 otherwise. Source: SEC filings.

INSURE_KEY_HUMAN_CAPITAL An indicator variable that is equal to 1 if the firm discloses that it holds key man life insurance on any of its employees, and 0 otherwise. Source: SEC filings.

KEY_HUMAN_CAPITAL_INTENSITY Total key man life insurance policy amounts to lagged book value of total assets. Source: SEC filings. 
KEY_EMPLOYEE_IS_DOCTOR An indicator variable that is equal to 1 if at least one of the firm's key employees has an MD or a $\mathrm{PhD}$ degree, and 0 otherwise. Source: www.nndb.com.

MISSING_EDUCATION A dummy variable that indicates that the key employee's educational background is missing. Source: www.nndb.com.

\section{Appendix D. Identifying “Key Employee” Disclosures}

For each firm-year observation, we search the company's 10-K filing for two types of phrases. First, we search for phrases such as "our key executives," "have essential employees," and "are critical managers." In particular, we identify any occurrence of all possible three-word sequences (i.e., " $<$ word1 $><$ word2 $><$ word3>") formed using the following groups of words:

group $1=\{$ are, have, many, multiple, on, our, several, upon $\}$

group $2=\{$ critical, crucial, essential, important, key, vital $\}$ and

group $3=$ associate, associates, employee, employees, executive, executives, manager, managers, officer, officers, personnel, talent\}.

Second, we search for the noun-verb-adjective triple formed using the following elements:

nouns $=\{$ employee, employees, executive, executives, manager, managers, officer, officers, personnel, talent $\}$

verbs $=\{$ are, is $\}$ and

adjectives $=\{$ critical, crucial, essential, important, key, vital $\}$.

We refer to firms that make either type of disclosure as the "disclose key employee" group.

\section{References}

Abowd, J.; J. Haltiwanger; R. Jarmin; J. Lane; P. Lengermann; K. McCue; K. McKinney; and K. Sandusky. "The Relation among Human Capital, Productivity, and Market Value: Building Up from Micro Evidence." In Measuring Capital in the New Economy. Chicago, IL: University of Chicago Press (2005).

Adams, R. B.; H. Almeida; and D. Ferreira. "Powerful CEOs and Their Impact on Corporate Performance." Review of Financial Studies, 18 (2005), 1403-1432.

Becker, G. Human Capital: A Theoretical and Empirical Analysis, with Special Reference to Education. Chicago, IL: University of Chicago Press (1964).

Borokhovich, K.; K. Brunarski; M. Donahue; and Y. Harman. "The Importance of Board Quality in the Event of a CEO Death." Financial Review, 41 (2006), 307-337.

Brynjolfsson, E., and L. Hitt. "Computing Productivity: Firm-Level Evidence." Review of Economics and Statistics, 85 (2003), 793-808.

Carhart, M. M. "On Persistence in Mutual Fund Performance." Journal of Finance, 52 (1997), 57-82.

Cremers, K. M., and Y. Grinstein. "Does the Market for CEO Talent Explain Controversial CEO Pay Practices?" Review of Finance, 18 (2014), 921-960.

Cummins, J. "A New Approach to the Valuation of Intangible Capital." In Measuring Capital in the New Economy, C. Corrado, J. Haltiwanger, and D. Sichel, eds. Chicago, IL: University of Chicago Press (2005).

Custódio, C.; M. A. Ferreira; and P. Matos. "Generalists versus Specialists: Lifetime Work Experience and Chief Executive Officer Pay." Journal of Financial Economics, 108 (2013), 471-492.

Custódio, C.; M. A. Ferreira; and P. Matos. “Do General Managerial Skills Spur Innovation?” Working Paper, Arizona State University (2014).

Daniel, K.; M. Grinblatt; S. Titman; and R. Wermers. "Measuring Mutual Fund Performance with Characteristic-Based Benchmarks." Journal of Finance, 52 (1997), 1035-1058.

Denis, D., and D. Denis. "Performance Changes following Top Management Dismissals." Journal of Finance, 50 (1995), 1029-1057.

Donangelo, A. "Labor Mobility and the Cross-Section of Expected Returns." Working Paper, University of Texas at Austin, (2011). 
Eisfeldt, A. L., and D. Papanikolaou. "Organization Capital and the Cross-Section of Expected Returns.” Journal of Finance, 68 (2013), 1365-1406.

Fahlenbrach, R. "Founder-CEOs, Investment Decisions, and Stock Market Performance." Journal of Financial and Quantitative Analysis, 44 (2009), 439-466.

Falato, A.; D. Li; and T. Milbourn. "Which Skills Matter in the Market for CEOs? Evidence from Pay for CEO Credentials.” Management Science, 61 (2015), 2845-2869.

Fama, E., and K. French. "Common Risk Factors in the Returns on Stocks and Bonds." Journal of Financial Economics, 33 (1993), 3-56.

Fama, E., and K. French. "Industry Costs of Equity." Journal of Financial Economics, 43 (1997), $153-193$.

Gompers, P. A.; J. Ishii; and A. Metrick. "Corporate Governance and Equity Prices." Quarterly Journal of Economics, 118 (2003), 107-155.

Hall, B. H.; A. B. Jaffe; and M. Trajtenberg. "The NBER Patent Citation Data File: Lessons, Insights and Methodological Tools." Technical Report, National Bureau of Economic Research (2001).

Hall, B. H.; A. Jaffe; and M. Trajtenberg. "Market Value and Patent Citations." RAND Journal of Economics, 36 (2005), 16-38.

Hayes, R., and S. Schaefer. "How Much Are Differences in Managerial Ability Worth?" Journal of Accounting and Economics, 27 (1999), 125-148.

Hempell, T. "Do Computers Call for Training? Firm-Level Evidence on Complementarities between ICT and Human Capital Investments.” ZEW Discussion Paper No. 03-20 (2003).

Hirshleifer, D.; A. Low; and S. H. Teoh. "Are Overconfident CEOs Better Innovators?" Journal of Finance, 67 (2012), 1457-1498.

Israelsen, R. "Investment-Based Valuation and Managerial Expectations." Working Paper, Indiana University (2011).

Johnson, B. W.; R. Magee; N. Nagarajan; and H. Newman. "An Analysis of the Stock Price Reaction to Sudden Executive Deaths: Implications for the Managerial Labor Market.” Journal of Accounting and Economics, 7 (1985), 151-174.

Kaplan, S. N.; M. M. Klebanov; and M. Sorensen. "Which CEO Characteristics and Abilities Matter?" Journal of Finance, 67 (2012), 973-1007.

Kaplan, S. N., and L. Zingales. "Do Investment-Cash Flow Sensitivities Provide Useful Measures of Financing Constraints?” Quarterly Journal of Economics, 112 (1997), 169-215.

Karolyi, S. "Personal Lending Relationships." Working Paper, Yale University (2013).

Kogan, L.; D. Papanikolaou; A. Seru; and N. Stoffman. "Technological Innovation, Resource Allocation, and Growth.” Technical Report, National Bureau of Economic Research (2012).

Kortum, S., and J. Lerner. "Assessing the Contribution of Venture Capital to Innovation." RAND Journal of Economics, 31 (2000), 674-692.

Lamont, O.; C. Polk; and J. Saá-Requejo. "Financial Constraints and Stock Returns." Review of Financial Studies, 14 (2001), 529-554.

Lev, B.; S. Radhakrishnan; and W. Zhang. “Organization Capital.” Abacus, 45 (2009), 275-298.

Levhari, D., and Y. Weiss. "The Effect of Risk on the Investment in Human Capital." American Economic Review, 64 (1974), 950-963.

Murphy, K. J., and J. Zabojnik. "Managerial Capital and the Market for CEOs." Working Paper, University of Southern California (2007).

Pastor, L., and R. Stambaugh. "Liquidity Risk and Expected Stock Returns." Journal of Political Economy, 111 (2003), 642-685.

Roberts, M. R., and T. M. Whited. "Endogeneity in Empirical Corporate Finance." Simon School Working Paper No. FR 11-29 (2013).

Trajtenberg, M. "A Penny for Your Quotes: Patent Citations and the Value of Innovations." RAND Journal of Economics, 21 (1990), 172-187.

Warner, J.; R. Watts; and K. Wruck. "Stock Prices and Top Management Changes." Journal of Financial Economics, 20 (1988), 461-492.

Wermers, R. R. "Is Money Really 'Smart'? New Evidence on the Relation between Mutual Fund Flows, Manager Behavior, and Performance Persistence.” Working Paper, University of Maryland (2004). 